\title{
UMA SOLUÇÃO MORANIANA AO PARADOXO DE MOORE
}

\author{
Eduardo Ferreira das Neves Filho \\ Universidade Federal de Pelotas
}

\begin{abstract}
In this paper we defend an alternative solution to Moore's Paradox (PM). To achieve this aim, after presenting the problem in its more general characterization, we establish a set of conditions that we judge necessary for an adequate analysis of the problem. With those set, we defend a solution to Moore's Paradox inspired in R. Moran's perspective. When rereading certain comments of the Wittgenstein's Philosophical Investigations, Moran holds that Moore-paradoxical sentences disclose a shock of accesses of first and third person perspectives. We will defend that this peculiarity makes people to be in what he calls akratic (epistemic) state, i.e., compromised with irrational participations on certain language games. Finally, we try to fulfill those analysis conditions that we considered at the beginning.
\end{abstract}

Key-words: Moore's Paradox, belief, assertion, absurdity, paradoxality, avowal, epistemic akrasia.

Resumo: Neste artigo, defendemos uma proposta de solução ao Paradoxo de Moore (PM). Para isso, após apresentarmos o problema em sua caracterização mais geral, estabelecemos um conjunto de condições que julgamos necessário para uma análise do problema. Com ele em vista, defendemos uma solução a partir de reflexões de R. Moran, para quem, ao reler certas passagens das Investigações Filosóficas de Wittgenstein, sentenças Moore-paradoxais revelam um choque de acessos de primeira e terceira pessoas. Defendemos que esse choque de perspectivas faz com que as pessoas, em estado akrático (akrasia epistêmica) comprometam as suas participações racionais em determinados jogos de linguagem. Por fim, com essa leitura em vista, procuramos responder as condições de análise que propusemos ao início.

Palavras-chaves: Paradoxo de Moore, crença, asserção, absurdidade, paradoxalidade, declaração, Akrasia epistêmica. 


\section{Introdução - condições de análise}

O que conhecemos hoje como o Paradoxo de Moore (PM) é um problema apontado por Moore, de modo explícito, em dois $\operatorname{artigos}^{1} \mathrm{da}$ década de quarenta. De modo ampliado, é discutido em um manuscrito incompleto, possivelmente escrito em 1944, editado por T. Baldwin (1993). Baldwin supõe que havia um primeiro manuscrito, escrito por Moore para uma conferência no Moral Sciences Club, que foi perdido; outro, escrito por Wittgenstein, comentando a 'descoberta' (do qual também não temos conhecimento do paradeiro), e, assim, os manuscritos que possuímos seriam a resposta para tal (dado que há menções a Wittgenstein neles). Data de 1944, também, uma carta escrita por Wittgenstein cumprimentando Moore por ter tocado, naquela conferência, em um 'ninho de vespas filosófico' (WITTGENSTEIN, 1980). Na Segunda Parte de suas Investigações Filosóficas (IF), Seção X, Wittgenstein batizou a descoberta 'Paradoxo de Moore', e, se as vespas filosóficas pareceram apáticas (WITTGENSTEIN, 1980) é porque estavam amainadas pelas confusões que se estabelecem no uso das palavras. Procura-se determinar o que há de estranho com conjunções como:

1. 'Está chovendo, mas não creio que esteja' $(p \& \sim \mathrm{B} p)$, e

2. 'Está chovendo, mas creio no contrário' ( $p \& \mathrm{~B} \sim p$ ).

Qual a natureza de uma suposta absurdidade presente nessas sentenças?

Essa pergunta pode ser estendida à sua asserção e à discussão sobre o fenômeno da crença, preocupando diferentes áreas da filosofia. Metáforas são usadas para chamar a atenção à dificuldade de se determinar a amplitude da questão. Por exemplo, Roy Sorensen ${ }^{2}$, em um livro que se origina com o

\footnotetext{
${ }_{1}$ Reply to my Critics, contido em The Philosophy of G. E. Moore, coletânea de artigos ed. por P. A Schilpp (Northwestern, Evanston: 1st. ed. 1942), e em Russell's 'Theory of Descriptions', publicado em The Philosophy of Bertrand Russell, coletânea de artigos também editada por P. A Schilpp, 1944. Porém, como é reconhecido por Baldwin, o problema apareceria implícito, e ainda de modo não sistemático, em seu livro Ethics, (Williams \& Norgate, London: 1912 - o que também é salientado por Gombay, A., Some Paradoxes of Counterprivacy. Philosophy, 63, pp. 191-210), bem como haveria mencionado várias vezes o problema, mesmo que brevemente, para seus alunos na década de 30 .

${ }^{2}$ Apesar de Sorensen propor-se, como afirmou, a um estudo anti-wittgensteiniano do Paradoxo de Moore, o que acaba por afastar este autor daquilo que propomos aqui, adiante.
} 
exame do PM, compara o problema a um blindspot, literalmente um ponto cego, re-significando a expressão da oftalmologia em termos de "uma área em que se falha ao exercitar entendimento, julgamento e discriminação" (1988, p. 2), ou ainda como uma espécie de inacessibilidade a certos tipos de proposições (1988, p. 3), as quais implicariam dificuldades na formação de nossas crenças. Parece ser reconhecido pela maioria dos comentadores que não responder a questão de por que é absurda uma asserção ou crença em proposições $^{3}$ Moore-paradoxais ${ }^{4}$ deixa aberta uma lacuna sobre 'algo' de nossas crenças, sejam mencionadas no âmbito da fala ou apenas pensadas, que não sabemos, e que possíveis saídas devem ser oferecidas para tanto.

Com isso, quer-se ressaltar a importância de um estudo do problema, focalizando um cenário em que essas sentenças são corrosivas. Por exemplo, anteriormente (NEVES FILHO, 1999) utilizei a metáfora do vírus de computador para apresentar o PM. Um programa que invade o disco rígido filosófico destruindo conceitos e definições, enfraquecendo posições. Soluções, nesse sentido, funcionariam como antivírus, e, para testar a eficácia dos mesmos, dever-se-ia identificar em quais programas o invasor havia se instalado, bem como a força das soluções em tais casos. Lá, a discussão apontava para conseqüências de uma compreensão do conceito de asserção e para um modo de abordar a investigação que remonta a G. E. Moore.

De acordo com Moore (1993, p.208), não haveria contra-senso em meramente dizer aquelas sentenças, a sua absurdidade residiria num modo especial de proferi-las, na asserção: ao asserir, implica-se crença na proposição asserida, o que seria assumido como uma espécie de regra (DE ALMEIDA, 1999). Ora, a absurdidade estaria, então, no desacordo entre o que é asserido no segundo conjunto e o que é implicado pela asserção do primeiro conjunto, em ambos os exemplos. Embora se reconheça que a observação de Moore é insuficiente para dar cabo do problema ${ }^{5}$, podemos afirmar que o autor oferece uma descrição do paradoxo que principia boa parte das discussões que são conhecidas na literatura sobre o PM.

\footnotetext{
${ }^{3}$ Geralmente, o termo proposição serve para referir objetos abstratos com os quais uma pessoa relaciona-se, quando tem, para com esses objetos, alguma das 'atitudes proposicionais epistêmicas' de uma família de atos mentais, que inclui o ato de crença. Considera-se, então, nessa perspectiva, que a expressão lingüística de uma proposição é uma sentença. Em alguns momentos neste trabalho trataremos de 1 e 2 como sentenças, às vezes como proposições. $O$ contexto da apresentação pretende esclarecer o porquê da diferença no uso desses termos.

${ }^{4}$ Essa nomenclatura é atribuída a Shoemaker (1996) ou Goldstein (1993).

5 Veja nossa crítica à perspectiva mooreana do PM (NEVES FILHO, 2008, tese de doutorado).
} 
Em primeiro lugar, as observações de Moore (em 1942 e 44), além de salientar o caráter absurdo da asserção de 1 e 2, como exposto antes, salientam o seu caráter paradoxal (segundo o Moore do manuscrito editado por Baldwin em 1993, p. 208): este surge quando notamos que o problema está presente apenas na primeira pessoa do presente do indicativo. Ele não aparece se conjugamos 1 e 2 no passado, no futuro, tampouco na terceira pessoa do singular': seria absolutamente plausível asserirmos que 'Está chovendo, mas ele não crê', pois, talvez 'ele' (uma pessoa qualquer) esteja, nesse momento, alterado por embriaguez. Em segundo lugar, Moore sustenta que se as mesmas proposições podem ser asseridas em outros tempos verbais sem absurdidade e não há problema que uma terceira pessoa assira as mesmas proposições ao se referir a mim (ou falar de mim), então "os significados das duas sentenças são tais que podem ambos ser verdadeiros ao mesmo tempo" (1993, p. 209). É importante observar que as sentenças 1 e 2, nesta leitura, são consideradas contingentes ${ }^{7}$. Para Moore, em um dos conjuntos haveria uma asserção sobre um estado mental do agente, uma crença, no caso, e no outro uma asserção sobre o tempo, não duas asserções contraditórias sobre o tempo ${ }^{8}$.

O que parece ser comumente notado é que, ao asserir 1 e 2 , as pessoas parecem estar se contradizendo. Note-se, porém, que, ao negá-las, suas negações "falhariam como verdades necessárias mesmo nas bocas dos nossos mais sensacionais meteorologistas" (SORENSEN, 1988, p. 15). Por isso buscase encontrar um possível 'parentesco' entre sentenças Moore-paradoxais e contradições formais, o que certamente faz pensar que "a lógica não é tão simples como os lógicos pensam que é” (WITTGENSTEIN, 1974, p.177).

Para efeito de análise do problema, encontramos na literatura recente que trata do PM a preocupação em se estabelecer um conjunto de condições de análise razoavelmente satisfatório que parece ter dupla finalidade: primeiro, identificar 'onde' está o problema e, segundo, proporcionar-lhe

\footnotetext{
${ }^{6}$ Conjugar o verbo crer na primeira pessoa do plural ocasionaria corolários de 1 e 2 (SORENSEN, 1988, p.16). Conjugar as sentenças na segunda pessoa do singular também pode, em certo sentido, ser paradoxal, como veremos mais adiante.

7 É importante notar que em uma certa leitura 'wiitgensteiniana' do PM, autores como Linville \& Ring (1991), Malcolm (1995), J. Heal (1994) e A. Collins (1996) sentenças Moore-paradoxais são contradições, digamos, 'disfarçadas'. Veja uma apresentação e crítica a essas posições em nosso trabalho de 2008 (tese de doutorado).

${ }^{8}$ Cabe destacar que Moore não parece distinguir os casos de 1 e 2 como diferentes tipos de 'problema', o que já foi notado por Williams desde 1979. Veja a referida distinção na Condição $\mathrm{E}$, exposta a seguir.
} 
uma solução adequada. A questão é estabelecer um 'alicerce' na investigação, que termine por oferecer uma explicação plausível para o que há de absurdo com 1 e 2, e que também se resolva o aspecto paradoxal do problema'. É importante assumir, no entanto, aquilo que pode parecer uma obviedade, mas que tem sentido diante daquilo que pretendemos realizar adiante: uma explicação deve ser o mais simples possível. Isto é, a absurdidade de 1 e 2 deve desaparecer em circunstâncias não-artificiais, se assim podemos dizer, sem que tenhamos de postular princípios e regras rígidos demais para tal finalidade. Particularmente, embora essa prerrogativa não se constitua propriamente como 'condição', é um custo que não se quer pagar.

\section{Primeira condição: condição $B^{10}$}

Deve-se esclarecer o uso do verbo epistêmico crer na primeira pessoa do presente do indicativo, de modo que se tenha uma explicação tanto para aquilo que se considera uma crença absurda em 1 e 2, quanto à absurdidade da asserção de sentenças moore-paradoxais ${ }^{11}$.

$\mathrm{Na}$ primeira caracterização do problema, realizada pelo próprio Moore, apontou-se à necessidade de uma distinção entre o que um falante qualquer assere e o 'conteúdo' (mental $\left.{ }^{12}\right)$ implicado pela asserção. No caso,

\footnotetext{
${ }^{9}$ Condições como as aqui encontradas são discutidas em muitos autores que comentam o PM, coincidindo, em suas perspectivas, em maior ou menor grau entre si. Aqui, não há o objetivo de proválas individualmente ou mesmo mostrar a possibilidade de uma simplificação. A escolha atenta à razoabilidade: parece razoável supor-se que as mesmas são necessárias identificar e solucionar o PM. Tomaremos como base (simplificando seu conjunto, além de reconsiderarmos algumas delas) as condições sugeridas por Williams em 1998 - "(i) identify a contradiction, or something contradiction-like, but not with the Moorean proposition itself; (ii) make this identification for assertion and belief; (iii) be equally plausible for (1) and (2); (iv) explain the role of circumstances in wich the absurdity disappears" (WILLIAMS, 1998, p. 287). Embora a solução que queremos construir não se aproxime daquelas oferecidas por Williams, tentaremos mostrar que é possível a utilização de condições semelhantes às suas na leitura do PM que nos propomos a oferecer. Podemos dizer que o conjunto dessas condições, baseado em Williams, é um conjunto mínimo de condições a serem satisfeitas, embora, dados os comentários de alguns autores que vinculam suas soluções a questões que não iremos tratar aqui, implique-se a possibilidade de agregar outras condições, se assim podemos chamá-las, secundárias.

${ }_{10}$ Chamamos essa condição de Condição $B$, pois queremos mostrar que na crença ( $\mathrm{B}$ - belief) 0 problema também permanece.

${ }_{11}$ Essa condição aparece em muitos autores. M. Green e J. N. Williams dão conta deste aspecto na introdução do livro Moore's Paradox: New Essays on Belief, Rationality, and the First Person (2007, p. 11): "If the explanation of the absurdity of Moorean assertion can be delivered, with little further explanatory cost, in terms of the absurdity of Moorean thought, then one seems to get both explanations parsimoniously".

${ }^{12}$ Compreende-se 0 termo 'mental' aqui como sinônimo de 'atividade psicológica'.
} 
aparece um desacordo entre o que é implicado pela asserção do primeiro conjunto e o que é asserido no segundo conjunto de forma explícita. Em suma, a razão do desacordo é, na perspectiva aberta por Moore, o que deveria ser explicado (solucionado).

Entretanto, há dificuldades em se sustentar soluções simplesmente assercionistas ao $\mathrm{PM}$, as quais tentam preencher lacunas deixadas pelo próprio Moore. Isso por que se pergunta se a dificuldade permanece quando apenas pensamos naquelas proposições, quando a absurdidade parece se manter não apenas no "contexto de proferimentos e atos de fala" (MORAN, 2001, p. 70) ${ }^{13}$. Assim, a explicação da absurdidade das sentenças Mooreparadoxais requer que se trate do problema de maneira a explicar também o que há de estranho com crença em 1 e 2 (WILLIAMS, 1998, p. 284-5). Um cuidado especial é destinado a compreender o acesso que temos (e como relatamos) a nossa vida psicológica, particularmente no sentido de como pensamos (e asserimos) o verbo doxástico crer na primeira pessoa do presente do indicativo. É tarefa identificar o uso categórico ${ }^{14}$ que se faz nesses casos que parece distinto, por exemplo, de seu uso em terceira pessoa, quando se “(...) pode falar e pensar sobre a vida psicológica de outra pessoa” (MORAN, 2001, p. 72) sem absurdidade (qual a razão dessa discrepância?).

Contudo, é importante deixar claro que apresentar essa condição, quando são destacados possíveis cenários de investigação (aparentemente distintos), não quer dizer que estejamos afirmando a necessidade de pesquisas independentes para tal fim. Apartar as discussões parece ser uma característica das soluções herdeiras da leitura mooreana do problema. Pelo fato de que se deve investigar um 'pensamento' de proposição Mooreparadoxal, tenta-se solucionar o PM, por exemplo, como o fez De Almeida $(2001,2007)^{15}$, em um âmbito exclusivamente mental. A análise, sob esse

\footnotetext{
${ }^{13}$ Aqui pode surgir a questão de se 0 ato de asserir uma proposição é um ato eminentemente linguístico, e nossa resposta é de que sim. Quem assere uma proposição, assere a alguém. Não parece haver sentido em asserir uma proposição a si mesmo. Tomada essa questão no último sentido, parece se estar falando, simplesmente, de um compromisso com a crença em uma dada proposição (ou, com a verdade de uma dada proposição). No entanto, resta saber em que medida esse comprometimento 'psicológico' pode ou não ser destacado de uma determinada prática linguística, o que certamente é apropriado perguntar-se no âmbito de resposta a essa condição.

${ }^{14} \mathrm{O}$ que significa um uso categórico da expressão 'eu creio que p', em primeira pessoa, é objeto de investigação a seguir.

${ }^{15}$ De Almeida (2001) incluiu uma condição de análise que assevera que se deve considerar, pela crença absurda, o agente doxástico irracional, a Condição $R$, da racionalidade epistêmica; em seu mais recente trabalho (2007), a prerrogativa é semelhante: mostrar que a crença em 1 e 2 não pode ser racionalmente
} 
ponto de vista, procura identificar como uma crença deve ser racionalmente sustentada. Crer-se em 1 ou 2, então, é considerado um caso de irracionalidade. E, se é irracional crer em 1 e 2, então se tem, como consequência, um motivo para que seja absurda a sua correspondente asserção: trata-se o problema da relação entre as crenças absurdas de 1 e 2 e suas asserções por meio do princípio de "que o que pode ser (coerentemente) acreditado constrange o que pode ser (coerentemente) asserido" (SHOEMAKER, 1996, p. 76).

Para fins argumentativos queremos afirmar que esse tipo de aproximação não é o mais adequado. A linguagem é tomada no sentido puramente designativo, compreensão fortemente atacada por Wittgenstein com sua crítica à Concepção Agostiana de Linguagem ${ }^{16}$. Ou seja, não se observa o uso de verbos epistêmicos: não há análise fora da linguagem, uma dificuldade que muitos comentadores parecem desconsiderar.

Podemos lembrar que há usos 'coerentes' de expressões na fala cotidiana que não implicam, por exemplo, um compromisso das pessoas que asserem com crenças ou alegações de conhecimento, como em 'Eu pensei ter dito para você esperar no carro' (MORAN, 2001, p. 71): aí há uma função lingüística específica. Do mesmo modo, há que se investigar a função específica do verbo epistêmico 'crer' em um sentido psicológico (e mesmo epistêmico) e lingüístico, porém, sem que com isso se tenha de postular domínios independentes de investigação para dar conta da absurdidade de 1 e 2 - as soluções devem ser complementares.

Em suma, ao se propor a Condição $B$ não se quer separar radicalmente 'universos' de pesquisa. É preciso orientar a investigação de

sustentada, embora a condição R não seja mencionada explicitamente. Ou seja, tenta-se mostrar caminhos que, por um lado, garantam a racionalidade de agentes, e, por outro, quando não observados, façam dos agentes irracionais por serem incoerentes. Veja como mostrar que esta última solução de De Almeida parece equivocada como pretensão de solução ao PM em nosso trabalho de 2008 (tese de doutorado).

16 De acordo com Glock (1996, p. 370), cinco teses estão associadas por Wittgenstein à Concepção Agostiniana de Linguagem: "a) cada palavra possui 'um significado'; b) todas as palavras são nomes, isto é, sucedâneos de objetos; c) o significado de uma palavra é o objeto do qual é um sucedâneo; d) a conexão entre as palavras (nomes) e seus significados (referentes) se estabelece por uma definição ostensiva, que determina uma associação mental entre palavra e objeto; e) as sentenças são combinações de nomes". Há duas consequências dessa concepção que são examinadas por Wittgenstein: "f) a única função da linguagem é representar a realidade: as palavras referem; as sentenças descrevem (PI, § 21-7); g) a criança só é capaz de estabelecer a associação entre uma palavra e um objeto por meio do pensamento, o que significa que deve possuir de antemão uma linguagem privada, para que possa aprender a pública (PI § 32)" (Id. Ibid.). 
modo a "explicar de que maneira verbos como 'crer' que servem para descrever um estado mental de uma pessoa em seus usos na terceira pessoa e no passado perdem essa função e assumem um papel completamente diferente no caso do uso da primeira pessoa do presente do indicativo" (MORAN, 2001, p. 71-2), e também expandir-se a discussão de modo a proporcionar uma saída à absurdidade da asserção de 1 e 2 .

Também é importante frisar que o cumprimento desta condição pressupõe que se possa explicar a característica 'absurda' de uma asserção e de um 'pensamento' de proposição Moore-paradoxal, mas também sua paradoxicalidade. Ou seja, não basta explicar por que é absurdo pensar ou asserir, em primeira pessoa, uma sentença Moore-paradoxal, mas por que aquilo que não é permitido em primeira pessoa não é nem absurdo, nem paradoxal, quando asserido e pensado na terceira pessoa do presente. Isso implicará a transmissibilidade de crenças de uma terceira pessoa para a primeira pessoa do indicativo, o que está mais bem explicado na Condição E, a seguir.

\section{Segunda condição: condição $\mathrm{C}^{17}$}

Deve-se identificar qual é o 'aspecto' contraditório de 1 e 2, sem que sejam, literalmente, identificadas como contradições formais.

É comum relacionar-se uma sentença Moore-paradoxal, principalmente ao ser asserida, com um caso padrão de contradição, assim como a Lógica Clássica exemplifica a contradição em sua forma padrão ( $p \& \sim p$ ). Porém, desde Moore, sugere-se que 1 e 2 não são contradições formais, pois, ao negá-las, não obtemos tautologias (SORENSEN, 1988, p. 15). Novamente, o compromisso se dá ao tentarmos esclarecer algumas propriedades do uso do verbo crer na primeira pessoa do indicativo - aspecto que conecta essa condição a Condição B - pois, é necessário investigar como este uso específico proporciona a uma sentença Moore-paradoxal a aparência de contradição.

Williams (1998, p. 284 e 288-9) propõe uma proibição ao fato de se tentar mostrar a simples equivalência entre uma sentença Moore-paradoxal e uma contradição. Seu ataque se dá principalmente a Linville \& Ring (1991),

\footnotetext{
${ }^{17}$ Chamamos essa condição de Condição C, indicando que é a condição da (c)ontradição: mostrar o que faz uma sentença Moore-paradoxal 'parecer' uma contradição.
} 
autores que pretendem mostrar que é feito o mesmo movimento linguístico ao asserir-se diretamente $p$ e 'eu creio em $p$ ', o que implicaria que 1 e 2 seriam contradições disfarçadas. No que nos toca, será importante observar se essa interpretação pode estar adequada com uma leitura wittgensteiniana do problema que queremos sustentar nesse trabalho. Como destaca Williams (1998, p. 288), Wittgenstein, na carta a Moore, ao contrário daqueles intérpretes, parece admitir que sentenças Moore-paradoxais têm aspecto de contradições, mas não o são literalmente. Qual é, então, o aspecto contraditório de 1 e 2 ?

\section{Terceira condição - condição $\mathrm{E}^{18}$}

As condições $B, C$ serão necessárias para uma explicação do problema se é possível "explicar a posição das circunstâncias nas quais a absurdidade [e a paradoxalidade, acréscimo nosso] desaparece[m]" (WILLIAMS, 1998, p. 287). Esta solução deve dar conta tanto do caso de 1, quanto de 2.

A satisfação mínima da Condição E diz respeito aos casos de 1 e 2 . Mas, não somente a eles. Consideremos a seguinte dificuldade ${ }^{19}$ : alguém pode asserir uma sentença, por exemplo, 3 - 'Teu pai te ama, mas você não acredita nisso', sem nenhuma absurdidade. Aqui, o caso é bastante semelhante a asserção na terceira pessoa, as pessoas parecem poder descrever as crenças das demais. Porém, se a pessoa a quem o pronome 'você' é endereçado acredita em 3, então parece acreditar 'Meu pai me ama, mas não creio', uma sentença Moore-paradoxal ${ }^{20}$. A pergunta seria então: por que os outros podem falar (o que acreditam sobre) de mim sem absurdidade, e eu não posso crer naquilo que manifestam sobre a minha pessoa? Se é verdade que notamos o problema somente na primeira pessoa do presente do indicativo, não é verdade que uma explicação deva estar centrada apenas nas razões (motivos) pelas quais não se pode ter garantias individuais para crer (e asserir) em 1 e 2 . Devemos mostrar o que acontece com as nossas crenças quando, sem absurdidade, alguém nos endereça 3, e como podemos desembaraçar esse nó.

\footnotetext{
${ }_{18}$ Condição $E$, nesse trabalho, indica a o cenário em que deve se desenvolver uma (E)xplicação do problema.

19 Hintikka (1969) tem sensibilidade para a questão. Sorensen (1988, p. 16) sistematiza o ponto. De Almeida $(2001,2007)$ discute 0 caso.

20 Este exemplo é extraído de De Almeida (2001). O autor o sugere como um problema para 0 confiabilismo de E. Sosa (p. 55-6). Porém, encontramo-lo muito semelhante em Hintikka (1969).
} 


\section{Em resumo:}

i) Necessita-se mostrar em que contexto a absurdidade de 1 e 2 desaparece, mas, ao mesmo tempo,

ii) Por que há 'verdades' sobre mim que outros podem crer/asserir com justificação e que, ao serem endereçadas a mim, eu não pareço podê-las crer, com a pena de parecer crer em um absurdo (em contextos em que aparentemente seria plausível crer no que me dizem)?

Ainda é importante notar que fazer desaparecer a absurdidade de 1 e 2 requer oferecer uma solução que possa dar conta de ambas as formas de sentenças. Williams (1982, p. 37) sustentou que não dizem respeito à mesma coisa. Considerando que normalmente ao se asserir $p$ é implicada a crença em $p$ (cujas razões para a implicação são disputadas desde Moore), o que é asserido no primeiro conjunto contrasta com o que é asserido no segundo conjunto de 1 e 2: 'não é o caso de que eu creio em $p$ ' e 'creio que não é o caso de que $p$ ', respectivamente. No caso de 1 , então, tem-se a tensão entre a crença em $p$ e a ausência de crença em $p$ e o prejuízo de que, acreditar-se em 1, seria sustentar uma impossibilidade lógica. Por outro lado, 2 é "logicamente possível, mas inconsistente"(WILLIAMS, 1982, p. 38) ${ }^{21}$. Acreditar-se em 2 é sustentar, como admite Williams, uma inconsistência no sistema de crenças.

Assim, agregado aos itens $i$ e ii, temos um terceiro:

Uma solução adequada deve responder satisfatoriamente aos casos de 1 e 2 (não necessariamente por meio de soluções distintas).

\footnotetext{
${ }^{21}$ Sorensen (1988), Williams (1996) e De Almeida (2001) propõem-se a estender a análise a outros casos de sentenças Moore-paradoxais não-evidentes. Conforme De Almeida (2001, p. 35), a atenção a esses casos non-standard nos faz perceber que também são absurdos, pois implicam os casos de 1 e 2 , ou ainda "because some (but not all) believers cannot rationally have them as objects of belief", além de que exemplificariam o mesmo tipo de 'fenômeno' que causa a absurdidade de 1 e 2. Aqui, nos contentaremos com uma explicação dos casos padrão - a mínima satisfação a essa condição. Se conseguirmos mostrar que 1e 2 são absurdas e, se outros casos podem ser comparados a esses, nosso trabalho terá cumprido papel importante. Apenas um dos exemplos mencionados por aqueles autores merecerá tratamento especial, pois envolve, a nosso ver, a transmissibilidade de crenças da segunda para a primeira pessoa do singular, conforme 0 item ii.
} 


\section{A perspectiva de primeira pessoa e o compromisso, na declaração, com a verdade do que penso e assiro: uma solução ao PM}

Procuraremos defender, aqui, uma proposta de solução ao PM em que as condições de análise elencadas antes possam ser satisfeitas. Para isso, tomaremos como ponto de partida as reflexões de Richard Moran sobre o PM, contidas em seu livro Authority and Estrangment: an essay on selfknowledge $e^{22}$. O autor, ao reler certos comentários de Wittgenstein, pretende mostrar que situações em que sentenças Moore-paradoxais são asseridas (ou pensadas) revelam um tipo de 'alienação' resultante de um choque de perspectivas nas pessoas, uma de primeira e outra de terceira pessoa, com consequências (indesejadas) sobre suas ações. $\mathrm{Na}$ mesma asserção, por meio de um acesso de primeira pessoa declaro como as coisas parecem assentadas para mim, e, no restante da conjunção Moore-paradoxal, desconfio que as coisas me possam estar assentadas desse modo, em terceira pessoa. A referida alienação é comparada por Moran com casos de akrasia epistêmica (termo a ser esclarecido adiante), vindo a se chocar com o ensejo das pessoas em se comportarem como agentes racionais, orientarem suas ações diante do mundo e dos outros.

O exame passa por mostrar que é possível se falar em uma autoridade de primeira pessoa, muito embora essa autoridade não possa ser concebida como uma espécie de privilégio e, desse modo, não passa por ter de admitir conseqüências mentalistas (extremas) à análise de nosso problema de pesquisa.

Embora o referido choque de perspectivas (os diferentes acessos de primeira e terceira pessoas) venha a diminuir a autoridade de primeira pessoa, com isso minando certo tipo de 'sentimentos' que uma pessoa tem em relação a si própria, a declaração, a manifestação pública desse 'estado' de alienação é que parece fazer com que ela não cumpra certas condições para alegar, por exemplo, ter conhecimento sobre o que assere, e essa é a consequência 'mais grave', digamos (e é o que pretendemos mostrar adiante),

\footnotetext{
${ }^{22}$ Agradecemos a sugestão de leitura do trabalho de Moran a P. Faria. Encontramos em Moran uma alternativa para responder condições de análise do PM que tínhamos em mente à época, e que as mantemos aqui. Tanto os méritos quanto possíveis erros de interpretação desse autor aqui, no entanto, são de nossa responsabilidade.
} 
em uma asserção pública de sentença Moore-paradoxal, já que a participação em certos jogos de linguagem estaria cancelada.

Nesse momento, tentaremos mostrar que uma solução ao PM, tal como foi concebida por Dall'Agnol (2007), não deveria prescindir de um exame prévio da solução de Moran. Dall'Agnol sustenta, apoiando-se em investigações tardias do 'segundo' Wittgenstein, a saber, presentes no $D a$ Certeza, que as pessoas descumprem uma das condições para se ter conhecimento em asserções de sentenças Moore-paradoxais. Concordamos parcialmente com sua análise. Porém, um exame de como 'funcionam' asserções do verbo crer em primeira pessoa é essencial a nosso ver para sustentar uma solução como quer o autor, já que implica realizar uma interpretação do uso do verbo crer em primeira pessoa. Queremos mostrar que esse ponto é importante para diferenciarmos a proposta de Dall'Agnol de certas soluções 'wiitgensteinianas' conhecidas.

\section{1) 0 choque de autoridades de primeira e terceira pessoas em sentenças Moore-paradoxais e a akrasia epistêmica}

As diferentes defesas da Concepção Apresentacional, como as chamaremos $^{23}$ seguindo Moran, procuram sustentar (com exceção de J. Heal) que a função auto-referencial para o verbo crer está vedada, isto é, uma asserção de 'eu creio que $p$ ' tem o mesmo valor linguístico de ' $p$ ', não há nada 'sobre' o 'eu' sendo dito, mas apenas sobre a proposição ' $p$ '. Entretanto, adotar essa posição parece proibir qualquer autoridade de primeira pessoa, na medida em que parece implicar não haver possibilidade, se as coisas assim o são, de a pessoa estar enganada em relação as suas crenças. Em geral, se pretende mostrar que 'eu creio que $p$ ' é equivalente a ' $\mathrm{p}$ ', simplesmente, e, então, não há paradoxo, apenas um caso, digamos, de 'contradição disfarçada'.

Para Moran (2001, p. 73), Wittgenstein considerou essa possibilidade de leitura do problema (como comunga a Concepção Apresentacional), isto é, por uma via expressivista, mas pareceu rejeitá-la. O centro da argumentação de Moran, lendo o filósofo austríaco, é destinado a mostrar que há certo tipo de 'cegueira' relacionada à perspectiva de primeira pessoa, mas isso não

\footnotetext{
${ }_{23}$ Para um maior conhecimento dos autores que estão englobados na Concepção Apresentacional, e de suas respectivas propostas de solução ao PM, veja nosso trabalho de 2008 (tese de doutorado do autor). Agradecemos a sugestão de nomenclatura (Concepção Apresentacional) à Janyne Satler.
} 
significa dizer que seja impossível sustentar que uma pessoa fale ou pense sobre si mesma de um modo bastante peculiar. Afinal, por que teria Wittgenstein afirmado que "se houvesse um verbo cujo significado fosse 'crer falsamente', não haveria significado para qualquer primeira pessoa no presente do indicativo" (WITTGENSTEIN, IF., 2001, p. 162)? Se não há significado para 'crer falsamente' no presente do indicativo, parece, então, haver significado para 'crer' nessa mesma conjugação.

Como isso pode ser mostrado? Moran (2001, p. 74) observa que em condições normais, a relação de uma pessoa com suas crenças obedece àquilo que denomina de Condição da Transparência ${ }^{24}$ : "com respeito à crença, a alegação de transparência é a de que, da perspectiva de primeira pessoa, eu trato da questão de minha crença sobre $p$ como equivalente a questão da verdade de $p$ ” (2001, p. 63). Essa condição é importante, já que responder 'por que creio em $p$ ?' é determinar se aquilo em que creio é verdadeiro, ou não ${ }^{25}$. Declaro que 'creio que $p$ ', se $p$ for verdadeira, e 'não creio que $p$ ', se $p$ for falsa. É por meio dessa relação de transparência que formo minhas crenças sobre o mundo, e será por meio das crenças que tenho sobre o mundo que orientarei, em geral, minhas ações. Esse seria o modo 'normal' de uso da expressão 'eu creio que $p$ '. Entretanto, é preciso dizer que há uma diferença entre o fato de se $p$ e a crença de uma pessoa em $p$ : "uma coisa é estar chovendo, e outra para mim (ou para qualquer pessoa) acreditar que está” (MORAN, 2001, p. 74), e, de acordo com Moran, Wittgenstein não se oporia a essa distinção.

Há como se falar de 'duas' compreensões da expressão 'eu creio que $p$ ' que revelam, por seu turno, diferentes perspectivas de acesso que uma pessoa tem sobre suas crenças. Por um lado, declarar publicamente que se crê em alguma coisa é expressar "o fato de que não é uma questão aberta para mim se está chovendo ou não” (MORAN, 2001, p. 74). Por outro lado, ao considerar minha falibilidade, posso desconfiar que as coisas se passem necessariamente assim como as concebo (acredito), já que minha crença,

\footnotetext{
${ }^{24}$ Transparência, aqui, não diz respeito a uma pretensa infalibilidade em relação as minhas crenças, mas à capacidade de ser transparente ao mundo ao declarar como as coisas me parecem assentadas, diferindo da tese da transparência em um sentido, digamos, 'cartesiano'.

${ }_{25}$ Adiante, pretendemos esclarecer como a alegação da transparência pretende ser distinguida, por Moran, das alegações da Concepção Apresentacional.
} 
distintamente do fato $p$ ele mesmo, pode ser falsa ${ }^{26}$; isso indica um choque de perspectivas ou acessos que uma pessoa pode ter em relação as suas crenças.

\subsubsection{Os acessos de primeira e terceira pessoas}

Para Moran, o 'choque' de perspectivas ou acessos de uma pessoa sobre suas crenças, um em primeira e outro em terceira pessoa, gera, em sentenças Moore-paradoxais, um "conflito de autoridades” (BESUNSAN, 2007, p. 252), não havendo uma instância de decisão que permita arbitrar necessariamente sobre um caso ou outro:

O acesso de primeira pessoa as minhas crenças é o que permite me dar conta do que eu acredito por meio de uma relação de transparência: para saber o que penso acerca de alguma coisa, basta investigar essa coisa (para saber o que outra pessoa pensa acerca de alguma coisa, não basta investigar essa coisa). $\mathrm{O}$ acesso de terceira pessoa à minhas crenças é o que eu estou pronto a me auto-atribuir para explicar meus comportamentos. $\mathrm{O}$ acesso de primeira pessoa está associado ao que eu, em alguma medida, me comprometo, a crenças que passaram, em alguma medida, pelo meu crivo. As crenças que eu acesso por uma via de terceira pessoa podem ser crenças que eu não me dou conta, ou crenças que eu não estaria disposto a endossar ou que não passariam pelo meu crivo (BESUNSAN, 2007, p. 254).

Apontar para esses dois acessos não é uma questão tranquila de se compreender, se algumas distinções não forem realizadas. Cada um dos acessos parece sugerir uma diferença de 'níveis' quando procuramos conceber uma pessoa como sujeito psicológico. A alegação de transparência diz que “crer é tomar algo como verdadeiro" (MORAN, 2001, p. 75). Por um lado, a minha crença, então, parece ser de algum modo uma extensão daquilo que já concebi em minha mente em contato com o mundo. As crenças de outra pessoa, por outro lado, representam fatos (psicológicos, segundo Moran) para

\footnotetext{
${ }^{26}$ Central na argumentação é notar que se não pode ser o caso de que minhas crenças sejam diferentes de como as coisas se passam 'lá fora' é negar que haja um mundo que existe independentemente delas (MORAN, 2001, p. 74-5).
} 
mim, que podem ou não vir a alterar o modo como vejo o mundo, podendo ou não alterar uma eventual crença que eu possua: elas me servem de evidências, portanto, para crer.

Mas, em relação a mim mesmo, qual distância pode haver entre aquilo que creio e como as coisas se apresentam para mim? Nesse caso, não parece haver distância alguma. Uma leitura de uma passagem da Seção X das IF onde Wittgenstein trata do PM é relembrada por Moran: "Alguém pode desconfiar de seus próprios sentidos, mas não de sua própria crença” (WITTGENSTEIN, IF, 2001, p. 162). Moran observa que, diferentemente das crenças de outra pessoa, nas quais posso confiar ou não, confiar ou desconfiar de minhas próprias crenças não faz sentido em declarações de primeira pessoa. Isso não significa dizer que minhas crenças sejam inderrotáveis, ou que se acrescenta as minhas crenças uma força sui generis em relação as minhas impressões dos sentidos. Em relação às crenças das outras pessoas e às impressões dos sentidos a questão se desenvolve no domínio da experiência, independentemente de quão bem assentadas minhas impressões estejam e de quanto (e como) as crenças dos outros possam me servir de evidência.

A relação que se estabelece entre minhas crenças e entre aquilo em que acredito não é matéria empírica, nem se desenvolve mediante nenhuma relação evidencial, ela é categórica: "falar da crença de uma pessoa é apenas falar de sua convicção sobre os fatos, e não de alguma coisa adicional de que poderia estar convencida” (MORAN, 2001, p. 76). Isso implica também em uma diferença de 'níveis' quando se trata de estabelecer um paralelo entre a verdade de uma possível crença que eu tenha e a verdade da crença de uma terceira pessoa sobre um mesmo assunto, em muitas circunstâncias. A leitura da passagem das IF (WITTGENSTEIN, 2001, p. 162) citada acima não parece indicar que uma pessoa tenha "grande complacência" (Id. Ibid.) em relação as suas próprias crenças, visto que é possível que mudemos nossas impressões acerca do mundo ao estarmos em contato com ele, e com aquilo que nos dizem as pessoas, bem como observando seus comportamentos.

Entretanto, podemos lançar um olhar para como funcionam nossos jogos de linguagem e observarmos que pode ser o caso de que "o jogo de linguagem do informar [declarar] pode ser mudado de tal modo que o informar não significa informar o ouvinte sobre o assunto, mas sobre a pessoa que realiza a informação" (WITTGENSTEIN, IF., 2001, p. 162). A leitura, aqui, pode ser a de que uma crença, quando alegada em primeira pessoa, já está assentada para quem realizou a declaração, é um "julgamento 
no qual alguém chegou” (MORAN, 2001, p. 76). Esse uso é categórico, e difere, pois, "do tipo de coisa que alguém pode tomar como evidência sob a qual irá basear seu próprio julgamento” (Id. Ibid.). Outras pessoas podem tomar meu julgamento como base ou evidência para assentarem suas próprias crenças, mas eu não possuo esse mesmo recurso para aplicar a mim mesmo, a não ser tratar do mundo por uma via de transparência (após ter julgado se há base, evidências para minhas crenças, tanto em contato direto com os mais diferentes assuntos, quanto tomando as crenças de outras pessoas como base ou evidência).

Enquanto a relação que tenho com as crenças dos outros é empírica, a relação que tenho com minhas crenças é categórica, pois "sobretudo ser um crente é estar comprometido com a verdade de várias proposições” (Id., 2001, p. 77). Caso não possua confiança em um assunto qualquer para realizar meu julgamento a respeito, então não terei a correspondente crença sobre isso. Estar em dúvida não compromete a perspectiva categórica na qual devo conceber as crenças que tenho no presente. Pode-se dizer que a perspectiva de primeira pessoa 'liga' aquilo que diz respeito a minha 'vida psicológica' com aquilo com que me comprometo publicamente ao realizar declarações.

Notar essa característica peculiar do acesso de primeira pessoa será importante para entendermos, posteriormente, o cenário em que sentenças Moore-paradoxais nos causam estranheza e são absurdas, tanto pensadas, quanto asseridas. A questão será notar que há uma lacuna que se estabelece entre a relação categórica que estabeleço com minhas crenças, por um lado, e a correspondente incerteza que uma posição de terceira pessoa em relação a mim mesmo pode causar, por outro. Afinal, meu acesso categórico de primeira pessoa não é de privilégio, no sentido de que postule infalibilidade no contato que estabeleço com o mundo.

Pelo contrário, temos, inclusive, muitas crenças que não podem ser 'inspecionadas' no sentido de um 'olho interno' que seja capaz de realizar uma vistoria em nossas mentes ${ }^{27}$. Novamente: ter um acesso categórico de primeira pessoa às nossas crenças, considerá-las por uma perspectiva transparente não significa ter sobre elas grande complacência. Isso abre a possibilidade de que haja conflito, em certas circunstâncias, sobre determinadas crenças que não considere estar apto a assegurar de mim

\footnotetext{
${ }^{27}$ Por isso é pouco, para não dizer nada, plausível aceitarmos a disciplina de uma vida regrada por princípios epistêmicos, tais quais sustentados nas leituras do PM que são, de certo modo, 'mentalistas'. Veja as soluções de J. Williams (2007) e De Almeida (2007), por exemplo.
} 
mesmo. Talvez sequer me sinta seguro para garanti-las em solilóquio, nem declará-las, pois não sinto que essas crenças possam realmente ser 'minhas'. Contudo, dessa possível 'alienação' uma série de conseqüências advirão para minhas ações como um agente racional, o que pretendemos discutir a seguir.

A relação de transparência que estabeleço com minhas crenças não é infalível, pois o compromisso com a verdade de uma dada proposição em que acredito é algo puramente subjetivo, podendo ou não 'a flecha atingir o alvo'. Isso poderia sugerir diferentes "metáforas de interioridade” (MORAN, 2001, p. 78), supondo-se que o 'conflito' entre o mundo (o que está 'lá fora') e o que se passa na mente de uma pessoa (o que está 'aqui dentro') pudesse ser discutido em termos argumentativos deveras abstratos. No entanto, Moran propõe-se a mostrar que a relação entre 'vida psicológica' e verdade pode ser construída sem se ter de admitir uma cisão tão obscura dessa relação, tão problemática à discussão filosófica. Tratar do ponto, então, é compreender os dois tipos de acessos que uma pessoa pode ter sobre suas crenças, que citamos anteriormente: os acessos de primeira e terceira pessoas e o choque dessas perspectivas em sentenças Moore-paradoxais.

\subsubsection{0 choque de acessos de primeira e terceira pessoas e a akrasia epistêmica}

Tipicamente, o choque de autoridades de primeira e terceira pessoas é ilustrado por Moran tomando como bases casos de akrasia epistêmica ${ }^{28}$. Uma situação akrática pode ser exemplificada no caso de um jogador que decide abandonar seu 'vício' de jogar à mesa constantemente. Por um lado, ao tomar a 'decisão' de abandonar as mesas de cartas, essa pessoa compromete-se categoricamente com a verdade dessa proposição. Se tomar essa decisão, esse é o compromisso que tem de admitir (a si e publicamente). $O$ comprometimento que se auto-impõe não é construído, contudo, sobre bases empíricas, é um comprometimento categórico com o fato de abandonar as mesas de cartas, o que deverá orientar sua ação nesse sentido. Entretanto, essa pessoa tem, ao mesmo tempo, uma série de evidências (empiricamente

\footnotetext{
${ }^{28}$ Moran ilustra o ponto trazendo uma discussão supostamente originada em Sartre. Para maiores informações, veja-se Moran (2001, p.77-83). Akrasia, aqui, no sentido tomado por Moran, revela um estado de dissociação, revela justamente o choque de acessos que uma pessoa pode ter em relação as suas crenças. Por isso, o termo não é utilizado no sentido de uma incontinência ou fraqueza de vontade, mas como um caso típico-epistêmico. Adiante procuraremos esclarecer melhor esse uso, indicando que a discussão pode passar ao largo de uma perspectiva volitiva, que indica um uso corrente do termo.
} 
estabelecidas) para desconfiar de que irá fazê-lo: "e sobre esse ponto de vista sua 'resolução' é um fato psicológico sobre ele com certo grau de peso" (MORAN, 2001, p. 79).

Essas evidências, empiricamente construídas, admitindo-se que compõem um peso 'psicológico' sobre a questão, são as únicas evidências sobre as quais ele pode confiar para abandonar as mesas de cartas. Mas, elas mostram o contrário daquilo que se comprometeu categoricamente: sua constante dependência dos jogos. Com isso, a decisão que tomou parece carecer de 'base', como dizemos comumente, e naquela decisão ele não parece poder depositar confiança (MORAN, 2001, p. 80).

Em suma, a pessoa fica a procurar por evidências para parar de jogar em um lugar onde não poderá encontrá-las. Parece mesmo que a solução que a pessoa busca para o vício não é completamente sua, visto que seu compromisso categórico parece mais e mais (à medida que pensa nisso) distante de como as coisas aconteceram com ela até então: "ela procura confiança sobre sua própria conduta futura no nível empírico, mas então se dá conta que tal confiança teórica é completamente inadequada para acomodar sua mente, porque pode ser totalmente parasítica sobre sua resolução prática-transcendental” (Id. Ibid.). E ele só sente a necessidade de buscar por essas evidências porque não se sente capaz de abandonar as mesas de jogo, seu compromisso categoricamente estabelecido.

Esse cenário parece mostrar que, por um lado, tenho acesso sobre as minhas crenças, que as evidências que possuo são aquelas que me colocam na posição de ser um jogador inveterado ${ }^{29}$; mas, por outro, sou forçado a revisar minha conduta, a revisar coisas, por exemplo, que não quero admitir de mim mesmo ou coisas que necessito corrigir, mudar. Isso tem como consequência o fato de que

sem o acesso de terceira pessoa, nossas crenças não poderiam ser corrigíveis. Sem o acesso de primeira pessoa, elas não poderiam ser corrigidas assim como ninguém seria responsável por elas de maneira a retificá-las. Quaisquer crenças podem ser falsas e podem ser julgadas assim e

\footnotetext{
${ }^{29}$ Caso me encontre em estado 'akrático', tudo aquilo que construí para mim mesmo sob a base de evidências empíricas formam uma base teórica, segundo Moran, que acabará por minar minha tentativa de adotar, na ação, um comprometimento categórico com o abandono do vício.
} 
retificadas - isso porque elas são acessíveis por meio dessas duas direções (BESUNSAN \& PINEDO, 2007, p. 4).

Segundo Moran, a perspectiva de terceira pessoa força o agente a tentar substituir um ponto de vista teórico sobre si mesmo por um ponto de vista prático, isto é, força a pessoa a tentar agir de uma maneira controlada: "aqui eu apresentaria esse pensamento como uma tentativa de conduzir a perspectiva teórica como ajuda para os meus fins práticos” (2001, p. 81). No entanto, sei que posso recair a qualquer momento em meu vício de jogo, pois formo constantemente evidências (teóricas, pois são construídas sobre fatos do passado, a partir de minhas constantes recaídas no vício) que minam a possibilidade futura de que me afaste das mesas de cartas. Com isso, parece que as evidências (teóricas) que proporciono a mim mesmo querem constantemente me afastar da decisão de parar de jogar. A situação 'akrática' acaba, por isso, sendo de certo modo corrosiva para uma pessoa, pois parece sempre agregar mais e mais evidências contrárias as suas decisões.

Contudo, pode ser o caso de que haja certa constância em minha decisão de parar de jogar, isto é, posso ficar, às vezes, confiante em minha decisão, mantendo-me por ora afastado da constante preocupação com minhas recaídas. Mas, essa situação não funciona, para Moran, como uma barreira empírica entre eu e o jogo de cartas, pois a situação 'akrática' ensinou-me que a todo o momento preciso manter o que decidi. Caso contrário, minha decisão será quebrada, e então voltarei à estaca zero: "meu endosso em princípio é adequado ao modo como relato a mim mesmo as razões em favor de algum curso de ação” (MORAN, 2001, p. 82). Essa perspectiva teórica que me estabeleço só será efetiva se vier a produzir novas evidências de que posso permanecer afastado do jogo de cartas, e, com isso, que eu possa 'predizer' que não voltarei a jogar. Quando deixam de ter esse 'peso' ou função, isso quer dizer que novamente perdi os motivos para dizer estar resolvido sobre a questão e que posso, a qualquer momento, voltar a jogar.

Entretanto, há uma diferença entre a perspectiva de terceira pessoa que tenho sobre a minha pessoa e a perspectiva de terceira pessoa quando aplicada às demais pessoas. Nesse caso, as razões preditivas que formo sobre suas possíveis ações não se diferem das razões práticas a que elas parecem chegar. Não importa que eu considere que as razões que uma pessoa levou em consideração, por exemplo, para votar em certo candidato, são as piores possíveis. Ainda assim, sei que agirá (ou agiu) desse modo, e que isso faz 
parte daquilo que posso considerar seu 'estado psicológico', e é nisso que poderei confiar ou não, pois expressa um 'fato' sobre ela, assim como outros 'fatos' sobre o mundo que costumo apreender de outros modos.

É isso que faz com que uma terceira pessoa tome minha crença, por exemplo, de que está chovendo, como evidência para crer que chove. A ela é permitido confiar ou não que minha crença lhe servirá evidência para saber se está chovendo. $\mathrm{Na}$ perspectiva de primeira pessoa, ao contrário, "eu preciso reconhecer que a crença é minha (grifo nosso) para reter ou abandonar” (MORAN, 2001, p. 83). Tomar uma crença em primeira pessoa como um fato psicológico é estar persuadido por evidências, e essas evidências "não incluem o fato de eu estar persuadido" (Id. Ibid.). Posso ter uma série de evidências de que a bolsa de valores provavelmente entrará em colapso nos próximos meses. Entretanto, se essas evidências não são suficientes para que forme a crença de que devo tirar meu capital dos negócios de risco, permaneço comprando ações nesse período. Essa mesma confiança faz com que eu não tome como evidência, para sustentar a verdade de uma nova crença, a crença de meu amigo de que realmente a bolsa de valores entrará em colapso. Só tomaria sua crença como evidência se realmente não tivesse confiança de que posso seguir investindo sem problemas.

Vistas essas distinções, agora estamos em posição de começar a explicar o que há de absurdo e paradoxal com sentenças Moore-paradoxais.

Situações 'akráticas', tal como a do jogador que quer abandonar o seu vício de jogar, manifestam o choque de perspectivas ou acessos que uma pessoa tem sobre si mesma. Por um lado, há uma série de fatos psicológicos que constituem o modo como ela manifesta seu acesso ao mundo, obedecendo à chamada condição da transparência, ou seja, seu acesso transparente ao mundo em uma perspectiva de primeira pessoa. Por outro, há a introdução de um ponto de vista empírico ou teórico, a perspectiva de terceira pessoa em relação a si própria, que pode fazer com que a pessoa reproduza uma série de evidências que acumulou, as quais contrariam àquilo que pode pensar ou asserir transparentemente. Assim, a pessoa acaba pensando ou asserindo sentenças Moore-paradoxais: "teoricamente, esses são fatos (matters of fact) perfeitamente independentes, e posso em princípio reconhecer a possibilidade de sua co-ocorrência, assim como posso imaginar minha conduta futura conflitando com o que decido fazer agora" (MORAN, 2001, p. 84). Em outras palavras, posso imaginar que esteja chovendo, bem 
como que não tenho essa crença ou tenho a crença no contrário, por inúmeras razões.

O problema que surge desse possível choque de perspectivas, entretanto, é que haverá prejuízo quando considero a racionalidade de minhas ações, quando me considero um agente racional. Quando me considero desse modo, o faço exatamente porque considero o mundo de uma perspectiva transparente, pois minhas ações orientar-se-ão a partir de como o mundo está constituído para mim:

Como me concebo como um agente racional, a consciência de minha crença é consciência de meu comprometimento com sua verdade, um comprometimento com algo que transcende qualquer descrição de meu estado psicológico. E a expressão desse comprometimento repousa no fato de que meus relatos de minha crença estão obrigados a conformar com a condição da transparência: que eu posso relatar minha crença sobre $\mathrm{X}$ considerando (apenas) X (MORAN, 2001, p. 84).

A expressão de uma determinada crença é constituída mediante reflexão sobre o assunto em questão, e não diz respeito à "consideração da evidência psicológica para uma particular atribuição de crença” (Id. Ibid.). Isso mostra que não é possível se conceber o problema como originalmente foi discutido por Moore (bem como em algumas análises posteriores àquela de Moore). Se considerarmos apenas a perspectiva teórica que alguém pode ter de si, ou seja, a perspectiva de terceira pessoa, então as sentenças Mooreparadoxais, tanto pensadas, quanto asseridas parecem ter sentido. No entanto, sentenças Moore-paradoxais asseridas ou pensadas mostram claramente uma situação em que a condição da transparência falhou para a pessoa. Assim, é justamente essa falha de cumprimento da condição da transparência que aponta, para Moran, os limites de aplicação que o ponto de vista teórico sobre si mesmo traz à discussão, e o PM seria um exemplo claro desse limite.

Se, por um lado, uma ação racional pressupõe que a pessoa aja de acordo com a condição da transparência, por outro também é "um requerimento racional que alguém tenha um tipo de acesso as suas crenças que não é baseado em evidências de qualquer tipo” (Id. Ibid.). Parece ser desse tipo de convicção que Wittgenstein fala na Seção X das IF (tratando do PM) ao dizer que "alguém sente a convicção em si mesmo, não infere essa 
convicção de suas próprias palavras ou de sua entonação" (WITTGENSTEIN, 2001, IF, p. 163). Se há limites para uma pessoa tratar de si mesma de um ponto de vista de terceira pessoa, isso não invalida que essa pessoa possa, quando pensa sobre si mesma, em muitas situações, ou assere publicamente certo tipo de compromissos que estabeleceu a si mesma estar de algum modo autorizando que se forme uma determinada perspectiva sobre si.

Moran (2001, p. 85) corretamente observa que as pessoas não têm consciência de muitas de suas crenças, por exemplo, em contextos terapêuticos, e nesses casos normalmente não há, para elas, conformidade com a condição da transparência. Apenas após certificarem-se de que há evidências que lhes imputam determinadas impressões de abandono, ausência, etc., é que podem formar outras crenças e passar a agir de modo diverso, transparentemente em relação ao modo como vêem o mundo. Por um lado, não fosse esse o caso, seriam apenas autômatos e nunca revisariam aquilo que sentem, por exemplo, nem aquilo em que acreditam. Por outro, quando não estão convencidas mediante argumentos construídos junto a seu terapeuta, nem mediante suas próprias reflexões que essas ou aquelas crenças lhes possam estar assentadas, então permanecem sem poder cumprir a condição da transparência. Nesses casos, as pessoas até poderiam dizer 'eu creio que $p$, possivelmente indicando uma crença que teriam (para a qual ainda não se acham convencidas), como diz Moran (2001, p. 85), colocando a declaração entre parênteses, mas não permitiriam a verdade de $p$ propriamente. Aqui parece se adequar a seguinte observação de Wittgenstein àquela citada logo acima: "Verdade é: alguém não infere sua própria convicção das próprias palavras” (WITTGENSTEIN, 2001, IF, p. 163).

Essa interpretação parece validar aquilo que Wittgenstein também diz logo a seguir: "Assim é como penso: crer é um estado mental" (Id. Ibid.). Para ter acesso a esse estado, teria de "cuidar de mim como os outros fazem [em uma perspectiva de terceira pessoa], me ouvir falando, poder tirar conclusões daquilo que digo" (Id. Ibid.), com todos os limites que teria uma perspectiva dessa natureza, como já observamos.

Diagnosticar o desacordo em sentenças Moore-paradoxais, pois, é apontar para uma situação em que o agente tem sua racionalidade comprometida por não respeitar a condição da transparência. Ele não respeita a condição da transparência, pois sua crença não se encontra assentada, ele não tem garantias para sustentar, por exemplo, que crê que está chovendo (em primeira pessoa), pois parece ser possível, para ele, a crença de que não está chovendo ou de que não é o caso que acredita que está 
chovendo (ambas em terceira pessoa): "e, é claro, se não fosse um agente racional, não haveria vida psicológica para ter perspectivas empíricas sobre [isso] no primeiro caso" (MORAN, 2001, p. 84).

E, quem pensa ou assere proposições Moore-paradoxais, ou seja, estando em situações 'akráticas', sabe que está nesse estado: o inveterado jogador de cartas sabe que precisa abandonar o seu vício, mas tem evidências (teóricas/empíricas) para duvidar de que o possa conseguir a proeza (muito embora possa não saber - ainda - como sair dessa situação e ser transparente àquilo que assumiu categoricamente).

\subsection{Respondendo a condição B}

A Condição B, como expomos, assevera que devemos esclarecer o uso do verbo epistêmico crer na primeira pessoa do indicativo, de modo que possamos explicar a crença absurda em 1 e 2, bem como a consequente absurdidade das respectivas asserções. Para respondermos a essa condição devemos principiar a discussão notando que explicar a referida tensão “requer que vejamos o significado do termo psicológico 'crer' como unívoco lado a lado nos dois contextos” (MORAN, 2001, p. 87), isto é, tanto no âmbito das crenças de uma pessoa, como nas respectivas asserções que elas podem realizar.

Ao declarar (to avow) que 'creio que p', minha declaração informa, por meio de meu comportamento, uma provável atitude explicativa para a respectiva crença que tenha a respeito de 'p'. Isso mostra, para Moran, que "em princípio as 'duas atitudes' nunca poderiam ser completamente de tipos diferentes” (2001, p. 87), a saber, reportar e declarar uma crença. Novamente, se esse fosse o caso, teríamos as mesmas dificuldades de mostrar a tensão que fora originada na exposição mooreana do problema e afiliadas: parece que olhamos 'para dentro' e vemos as coisas de um jeito, e olhamos 'para fora' e vemos as coisas de outro jeito, o que é motivo de críticas de diversas naturezas ${ }^{30}$.

Quando declaro que 'creio que $p$ ', o faço na perspectiva de primeira pessoa. Fazendo isso, comprometo-me categoricamente com a verdade de $p$. Ao declarar categoricamente que 'creio que $p$ ', proporciono uma atitude responsável em relação a qualquer evidência psicológica de que $p$ seja o

30 Para maiores esclarecimentos, veja nossa tese de doutorado (2008). 
resultado (MORAN, 2001, p. 88) no contexto em que essa declaração foi realizada. No momento em que realizo a declaração de crença "não me beneficio de qualquer evidência psicológica” (Id., p. 87); na declaração, comprometo-me com os fatos para além de meu estado psicológico ${ }^{31}$, pois é na própria declaração que manifesto meu compromisso psicológico com $p$. Mesmo em contextos psicanalíticos essa prerrogativa está mantida (Id., p. 89). Normalmente as declarações de crença dos pacientes não são tomadas necessariamente como 'verdadeiras' no início da terapia, já que podem ter significado diverso de como as coisas se passam em suas vidas, e serem diferentes do modo como realmente se comportam. Aos poucos, no entanto, pacientes e o terapeuta vão construindo interpretações que possam substituir as crenças dos pacientes, mesmo que, em primeira instância, a interpretação se mantenha apenas em nível intelectual. Contudo, essas possíveis interpretações só terão validade na vida dos pacientes quando os mesmos não resistirem a outras possibilidades, internalizando os resultados da análise, e depois passando a agir de modo diferente. E, quando passam a agir de modo diferente, passam a declarar que acreditam, por exemplo, em $p$ de uma maneira categórica, agindo transparentemente em relação às coisas em que acreditam. Apenas nesse caso se pode dizer que o tratamento psicoterápico surtiu-lhes 'efeito'.

Por um lado, ainda não termos uma crença assentada significa que temos acesso àquilo que dizemos acreditar, muito embora não possamos sair do estado de akrasia simplesmente procurando, entre nossas evidências psicológicas já aparentemente constituídas, uma boa saída para o estado de tensão em que nos encontramos. Isso parece rejeitar qualquer explicação ao PM que mantenha uma divisão severa em termos de diferentes universos de pesquisa, uma das coisas que nossa Condição B procurou apontar como um erro em qualquer solução que se busque para o PM. O estado 'akrático' justamente revela a dificuldade ${ }^{32}$ de que nossa vida mental possa ser

\footnotetext{
${ }^{31}$ Aqui, pode surgir a questão da possível intenção de quem realiza a declaração. No entanto, do ponto de vista da audiência, interessa menos saber qual foi a intenção de quem realizou a declaração, já que dificilmente teremos como saber a real intenção de falantes ao participarem de jogos de linguagem - veja Williams (1994) e nosso artigo de 1999 para um panorama a respeito da insuficiência de soluções baseadas na intenção de falantes. A audiência pode pensar assim: o falante teve alguma intenção ao declarar que crê que $p$; independentemente dessa intenção, no entanto, ele acaba por assumir 0 compromisso com a verdade de $p$.

32 Visto que há contra-exemplos a muitos princípios epistêmicos onde a 'disciplina mental' das pessoas não alcança regramentos de ordem superior.
} 
organizada mediante a observação de princípios epistêmicos com o objetivo de uma futura tomada de posição que venhamos a realizar por meio de nossas ações.

Por outro, apenas quando a declaração categórica se mantém para garantirmos a predição de que não mais jogaremos cartas, isto é, quando nossa ação revelar que essa crença está constituída (o que requer revisão permanente), é que declarar que acreditamos em $p$ conforma com a condição de transparência: "ao declarar a intenção a pessoa está comprometida com o endosso prático da ação, e com a expectativa do futuro evento" (MORAN, 2001, p. 88). Novamente, princípios epistêmicos muito rígidos não dão conta, na prática, de mostrar por quais razões uma pessoa possa estar ciente de determinados comportamentos que são expressos em suas correntes declarações de crença. Posso acreditar, por exemplo, que tenho a 'mente aberta' em relação à igualdade entre homens e mulheres e, no entanto, comportar-me com elas de uma maneira 'machista': isso invalida, ao menos prima facie, uma crença de segunda ordem sobre minha crença de que $p$. No fundo, minha perspectiva de primeira pessoa, transparente ao mundo, apenas revela que ajo como um machista, e nada mais (e mais, como costumeiramente ajo, que nem sequer possa me encontrar em estado 'akrático). Minha declaração de que as mulheres são iguais aos homens, ademais, parece ser falsa por causa de minhas ações machistas em relação a elas - parece que, de algum modo, a Condição da Transparência falhou em casos como esses.

É nesse sentido que parece haver razões para dizer que "alguém pode desconfiar de seus próprios sentidos, mas não de sua própria crença” (WITTGENSTEIN, IF, 2001, p. 162). Pois, ao declarar que creio que $p$, declaro que essa não é uma questão aberta para mim, declaro transparentemente que assentei essa crença (muito embora seja óbvio que essa crença possa, dadas as devidas circunstâncias, ser falsa - esse é outro problema). Isso mostra por que a perspectiva de primeira pessoa é sempre privilegiada na vida (prática) de uma pessoa em relação às evidências empíricas (teóricas) que pode formar sobre si mesma - seu acesso de terceira pessoa:

A meta de tratamento [no caso de tratamentos psicanalíticos, por exemplo, acréscimo nosso], entretanto, requer que a atitude em questão seja conhecível pela pessoa, não através de um processo teórico de auto-interpretação, mas pela 
declaração de como pensa e se sente. Isto é, o que é para ser reparado pela pessoa não é apenas um conhecimento dos fatos que tem de si, mas o auto-conhecimento que obedece a condição da transparência (MORAN, 2001, p. 90).

Por um lado, Moran (2001, p. 90) observa que nem tudo o que conhecemos sobre nós mesmos precisa conformar a nossa capacidade de declaração. Entretanto, isso mostra que alguma coisa está errada, na medida em que não oferecemos uma posição acerca da questão. Uma declaração de crença ganha efetividade, por seu turno, porque mostra confiança da pessoa naquilo que supostamente associou por meio de um contato com o mundo, e isso significa que tem acesso àquilo que declara crer. Caso contrário, "estaríamos proporcionando que tudo fosse possível por meio de um 'acesso privilegiado', mas sem a consciência da pessoa de suas atitudes serem expressáveis por meio das [respectivas] declarações” (Id. Ibid.), e a vida psicológica dessa pessoa se tornaria opaca a si mesma.

Por outro lado, o acesso de primeira pessoa que temos as nossas crenças não é de privilégio devido a dois aspectos que podem aparecer separados, segundo Moran, mas que normalmente aparecem juntos. O primeiro deles, já identificado antes, é que "posso dizer aquilo que penso sem observação, evidência ou inferência de qualquer tipo” (MORAN, 2001, p. 91). Essa possibilidade está associada a um segundo aspecto: quando realizo uma declaração, ela diz respeito a seus respectivos objetos, ao modo como constituo o mundo ao obedecer a Condição da Transparência. Esse último aspecto não ganha um caráter de necessidade, visto que, como vimos, há casos em que não temos condições de endossar posições a respeito de determinados assuntos, casos em que a transparência falhou. A perspectiva de primeira pessoa, assim, está fortemente associada às ações que podem ser realizadas mediante declarações de crença, e essa 'autoridade' é que permite que as ações das pessoas sejam julgadas de um ponto de vista racional.

Essa última observação é importante para diferenciar uma forma de autoridade que conforma às respectivas atitudes que uma pessoa tem (e terá) sobre suas crenças daquele tipo de autoridade, ou acesso 'especial', que muitos autores defenderam, e que viria a admitir um 'olho interno' no sentido de escrutinar, introspectivamente, o conjunto de nossas crenças sobre o mundo e as coisas. Podemos, por exemplo, em uma terapia, irmos investigando quais são as razões para costumarmos fugir de relacionamentos que envolvam estabilidade, e, após algumas seções, colocarmos entre 
parênteses determinadas 'crenças' de que não estejamos cientes e que comporiam, digamos, nossa 'verdadeira' posição a respeito. Entretanto, também como já apontamos, permaneceremos fugindo dos relacionamentos dessa natureza se não nos sentirmos convictos para declarar que essas crenças que colocamos entre parênteses são realmente nossas (MORAN, 2001, p. 93), e a agir conforme o que declaramos.

Essas observações nos parecem adequadas para sustentar que uma solução satisfatória ao PM não deva passar por sublinhar domínios diferenciados de pesquisa. Quando se fala em mostrar o que há de absurdo com crenças em proposições Moore-paradoxais e aquilo que há de absurdo com as respectivas asserções, ao contrário, é mostrar que qualquer coisa que possa minar a crença que uma pessoa tem a respeito de um determinado assunto está diretamente vinculada ao modo como pode (se é que pode) declarar publicamente essa espécie de convicção. $\mathrm{O}$ compromisso 'psicológico' que uma pessoa tem com suas crenças não pode estar destacado de certas práticas linguísticas nas quais declara transparentemente o que compõe, para elas mesmas, um determinado acesso ao mundo. Aqui, pois, há complementaridade entre um caso e outro.

É nesse sentido que parece haver sustentabilidade para o princípio de Shoemaker: "o que pode ser (coerentemente) acreditado constrange o que pode ser (coerentemente) asserido”. A questão não pode ser apontar razões puramente intelectuais para dizer que uma pessoa, em dada crença, é incoerente, e que isso implicará que a correspondente asserção será da mesma forma incoerente; a questão aqui não pode ser matéria de designação. A função específica de uma declaração de crença em primeira pessoa é relevante, pois funciona como declaração daquilo que é o acesso imediato de uma pessoa a uma determinada crença. Quando falamos de crença, falamos concomitantemente de um estado psicológico e da possibilidade de declaração desse estado. Novamente, reportar e declarar uma crença não podem ser atitudes tão diferentes se queremos encontrar uma (dis) solução ao PM.

O próximo passo, então, deve ser verificar de que modo declarações de crença (obedecendo a Condição da Transparência) fazem referência ao falante e seu estado de crença correspondente. Desse modo se poderá dizer que a declaração diz respeito ao auto-conhecimento que o falante tem de si mesmo. Ao mesmo tempo, essa resposta tem de se diferenciar das posições da Concepção Apresentacional, funcionando, inclusive, uma crítica para tal.

Um dos argumentos centrais da Concepção Apresentacional repousa naquilo que podemos chamar de expressivismo: um falante não assere, nem 
reporta seu estado mental, apenas o expressa. Desse modo, asserir 'eu creio que $p$ ' é considerado o mesmo movimento lingüístico do que a simples asserção de $p$. Se a última funciona como expressão de uma crença, então a primeira também o faz. A tarefa, pois, tem de ser a de mostrar que há diferença entre meramente reportar uma crença, no sentido de qualificar o papel de uma declaração, como para Moran, e simplesmente expressá-la, o que é proposto nas leituras da Concepção Apresentacional.

Não fosse esse o caso, ou seja, se não há essa distinção, não saberemos como assegurar a autoridade que uma pessoa tem sobre aquilo que declara crer. Aqui, parece haver uma generalização, na Concepção Apresentacional, das conhecidas críticas de Wittgenstein à proferimentos de primeira pessoa, tais como nos exemplos utilizados pelo autor para rejeitar a possibilidade de uma linguagem privada. Sinteticamente, o que se pareceu querer mostrar nesses casos é que não haveria referência à própria pessoa em um proferimento como 'Eu tenho dor', mas 'comportamentos' como esses deveriam ser entendidos por meio de expressões (condutas) de dor, assim, que nesse tipo de proferimentos não haveria qualquer privacidade, qualquer remissão a algo que podemos chamar de auto-conhecimento. A verdade ou falsidade do proferimento em primeira pessoa, nesses casos, seria justificada mediante o comportamento de dor, prevenindo que nesse tipo de alegações surgisse a questão do 'conhecimento' (MORAN, 2001, p. 102). O expressivismo surge como uma rejeição, portanto, de toda a possibilidade de se engendrar o auto-conhecimento na perspectiva de primeira pessoa, o que é estendido às manifestações de crença pela Concepção Apresentacional: "assim a Concepção Apresentacional funciona como um argumento adicional em favor da concepção que proferimentos na forma de 'eu creio que $p$ ' são expressões da crença de uma pessoa, e não reportam sua crença” (Id. p.103).

No entanto, algo fica aberto nessa posição, já que expressões são expressões de alguma coisa. Se, em casos como de comportamento de dor, por exemplo, o argumento se desenvolve principalmente sobre sensações (experiência de dor, experiências visuais) - tentando-se mostrar que "então não é possível respeitar uma regra 'privadamente': de outro modo pensar que alguém obedece às regras seria a mesma coisa que obedecê-las” (WITTGENSTEIN, §202, 2001, p. 69) - não parece correto generalizar indiscriminadamente o argumento no sentido de extirpar do discurso significativo quaisquer remissões ao que poderíamos chamar de atitude (ou 
autoridade) de primeira pessoa. Se, por um lado, o argumento contra a possibilidade de uma linguagem privada ${ }^{33}$ chama a atenção para o fato de que não se pode seguir uma regra privadamente, e com isso afastando anseios de privacidade que remontam a Filosofia Moderna, desde Descartes, certos jogos de linguagem pressupõe, por outro lado, que faça parte de seus funcionamentos que um proferimento como 'eu creio que $p$, categoricamente declarado e obedecendo a condição da transparência, diga respeito à determinada convicção que o falante possui, diga 'alguma coisa' sobre o falante.

Assim, não é sem cabimento dizer que "quando classificamos um proferimento como uma afirmação ou relato, nós não estamos desse modo negando que também seja uma expressão" (MORAN, 2001, p. 103). Como Moran observa, reportar e expressar uma crença não são categorias excludentes. Ao declarar $p$, realizo uma ação, e, com essa ação, posso expressar diferentes coisas, entre elas, minha crença de que $p$. Essa concessão, no entanto, não significa dizer que, ao realizá-la, estejamos negando que declarações sejam expressões e, com isso, sustentando novamente certo conjunto de privilégios de primeira pessoa; afinal, declarações categóricas de primeira pessoa, conformes à Condição da Transparência, são públicas, e não movimentos intelectuais que só a pessoa em questão pode realizar - há regras para tanto, e é dessas regras que estamos falando aqui. A generalização argumentativa da Concepção Apresentacional erra por não reconhecer essa possibilidade: o argumento procura ser "a negação que membros dessa classe de proferimentos [de crença] possam mesmo funcionar como afirmações ou relatos” (Id. Ibid.). Então, aceitar o argumento da Concepção Apresentacional em toda a sua extensão é proporcionar uma espécie de opacidade que uma pessoa teria em relação as suas crenças, sublinhar a impossibilidade de que pudesse falar sobre aquilo que se constitui como 'estado psicológico'.

Reportar uma crença, isto é, manifestar uma perspectiva de primeira pessoa sobre as coisas, o mundo, enfim, sobre o modo como assentamos determinada crença, é um modo de expressão, só que expressão de um determinado estado psicológico. Essa possibilidade não pretende deixar de

\footnotetext{
${ }^{33}$ Para maiores esclarecimentos acerca do argumento wittgensteiniano contra a linguagem privada e sobre o significado de seguir uma regra com maiores detalhes, consultar GLOCK, H-J, Dicionário Wittgenstein. Tradução de Helena Martins. Rio de Janeiro: Jorge Zahar Editor, 1996, ou HACKER, P.M.S. Wittgenstein's Place in Twentieth-Century Analytic Philosophy. Oxford: Blackwell, 1996 e GLOCK, h. J. Wittgenstein. A critical reader. Oxford: Blackwell, 2001.
} 
lado que, em quaisquer declarações que uma pessoa venha a realizar, carregará consigo certas "responsabilidades de asserir tal julgamento" (MORAN, 2001, p. 104) $)^{34}$.

Se não houvesse a possibilidade de que declarações de crença pudessem ser tomadas como informações sobre a vida psicológica das pessoas, então não haveria a possibilidade de que se pudesse falar de bons resultados em terapias psicológicas. Por exemplo, quando vou a meu psicanalista e declaro uma série de crenças que tenho sobre minha relação com $\mathrm{X}$, reporto determinada crença que me faz possuir uma série de ressentimentos em relação a essa pessoa. $\mathrm{O}$ terapeuta, nesse caso, poderá ajudar-me a inferir que todas as evidências para a boa relação que tenho com $\mathrm{X}$ não estão 'transparentes' para mim, e poderei desse modo assentar (ou não) nova crença a respeito.

A declaração (avowal), desse modo, aparece como uma categoria distinta das informações (psicológicas - reports) e da expressão. Se a declaração também é uma expressão, todavia, expressão de uma convicção psicológica, fica difícil ver como a Concepção Apresentacional, particularmente alguns de seus autores, possam gerar uma contradição a partir de meras expressões de crença contidas em sentenças Mooreparadoxais $^{35}$. Não se fala apenas de $p$, mas categoricamente sobre $p$, e por isso a tensão fica difícil de ser gerada pelo expressivismo em todo e qualquer contexto. Todas as crenças com as quais me comprometo são crenças que aceito como verdadeiras (MORAN, 2001, p. 105), e, portanto, elas dizem respeito a mim. Ao declará-las, pois, as expresso. Ao declarar que 'creio que $p$, não perco a referência que tenho sobre $p$, unicamente pela razão de que posso transparentemente declarar essa crença ${ }^{36}$.

\footnotetext{
34 "The denial of this general possibility, as put forth in expressivism, is therefore more properly put forward as the claim that first-person expressions of pain or belief are mere expressions; that is, not to be included among the verbal expressions that are also assertions or reports of one's state" (MORAN, 2001, p. 104).

35 Voltaremos a esse ponto ao respondermos a nossa Condição C, adiante.

${ }^{36}$ Embora tenhamos enunciado nessa condição que temos de explicar tanto 0 caráter absurdo, quanto paradoxal presente nas sentenças Moore-paradoxais, responderemos 0 aspecto paradoxal do problema na condição a seguir, a saber, a Condição $\mathrm{E}$.
} 


\subsection{Respondendo a condição $E$}

A distinção entre acessos de primeira e terceira pessoa (que podemos ter de nós mesmos) é fundamental para compreendermos o que há de absurdo e paradoxal em pensamentos e asserções de sentenças Mooreparadoxais. Até aqui, nossa resposta ao problema de pesquisa passou por investigar algumas observações de Moran acerca da respectiva diferença de acessos, bem como de suas considerações sobre situações em que esse 'choque' de acessos acaba por comprometer a racionalidade das ações das pessoas. Podemos, agora com esse cenário em vista, especularmos adiante.

Quando uma crença é declarada (avowed), passa a exercer determinada função em um jogo de linguagem. Uma crença declarada está 'a meu dispor'

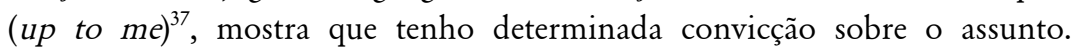
Embora seja consequência de algo que se passou 'em mim', agora ela serve de referência na declaração: quando indico minha convicção sobre o assunto. Isso aponta para uma diferença entre o que podemos chamar de um acesso genuíno de primeira pessoa as nossas crenças, o acesso de primeira pessoa, e o acesso meramente atributivo, de terceira pessoa (MORAN, 2001, p. 106). No primeiro, pelo fato de se constituir em declaração, é permitido que se extraia a posição da pessoa a respeito, apesar de que, do ponto de vista de quem recebe a declaração, o que está em jogo não seja as evidências (teóricas - empíricas) que a pessoa formou, mas sua própria convicção, agora declarada, que poderá servir de evidência para formar juízos sobre o assunto. Já o acesso de terceira pessoa, que, como vimos, pode servir para que a pessoa revise suas crenças, é meramente atributivo, apesar de se constituir como a única forma de conhecimento que uma pessoa pode ter de si mesma. Entretanto, é justamente esse acesso que termina por causar certa opacidade em atribuições de crença que alguém queira garantir para si. Por isso, não deve ser considerado um estado genuíno, pois não se tem, sob esse estado, condições de assegurar, em declarações, convicção sobre quaisquer assuntos.

Em suma, a crítica à Concepção Apresentacional nos mostra que temos acesso as nossas crenças, que existe certa forma de acesso, digamos, 'mental' àquilo em que acreditamos, porém, cujo "completo endosso (...)

\footnotetext{
${ }^{37}$ A tradução de crenças que estão up to me por "estão a meu dispor" quer indicar, apenas, que as respectivas crenças já me estão assentadas, sem mais a necessidade das evidências psicológicas que posso construir 'sobre mim'. Esse ponto é esclarecido adiante.
} 
anularia seu status de julgamento propriamente psicológico" (MORAN, 2001, p. 106). Não deve haver uma rejeição completa à possibilidade de que tenhamos acesso as nossas crenças, muito embora quando se fala na possibilidade desse acesso não se esteja falando em um acesso privado de garantia ou privilégio. Isso porque o que contará realmente serão as declarações de crenças que as pessoas realizam, as quais terão valor no jogo de linguagem em que se fazem apropriadas.

Assim sendo, "é a declaração que faz a diferença entre conhecimento meramente atributivo e consciência genuinamente de primeira pessoa” (Id. Ibid). Moran considera que a declaração é o 'veículo' para autoconhecimento, e acrescentamos que esse veículo é que permite que certas regras de certos jogos de linguagem possam ser executadas com garantias de entendimento, apesar de não haver nenhuma 'instância interna' que regule as crenças de uma pessoa, aparte seu contato direto com os objetos de crença, com o mundo, o que naturalmente obedece a condição da transparência:

Os propósitos da regulação de crença não requerem que a pessoa esteja envolvida aqui, sobretudo, e então não há necessidade de que a pessoa tenha consciência de seus conteúdos estarem sendo regulados. Visto desse modo, não há mais razão para pensar que a regulação de crença requeira mais consciência das crenças em questão do que há para pensar que a regulação dos batimentos cardíacos, respiração, ou metabolismo requerem um monitoramento consciente, ou mesmo uma criatura com a capacidade para consciência em geral. E, como essa comparação sugere, não somente tais atividades não parecem requerer o controle consciente da pessoa, mas parece que não poderiam requerer isso, pois é difícil imaginar como a vida prosseguiria se tal monitoramento fosse necessário para um funcionamento apropriado [disso tudo] (MORAN, 2001, p. 110).

Crenças e asserções de sentenças Moore-paradoxais são exemplos de situações em que a pessoa se encontra em um estado de dissociação, que revela que não podem, transparentemente, atribuir, na crença, qualquer coisa que pensam sobre determinados assuntos. Assim como o jogador inveterado de cartas, quaisquer pessoas assumem categoricamente que irão abandonar o vício e, na mesma conjunção, suspeitam que não consigam fazê-lo. Como 
não têm nenhum mecanismo a priori que as permita tomar a decisão, elas podem até mesmo permanecer em seu estado 'akrático', o que consequentemente as impedirá, em muitas circunstâncias e em muitos jogos de linguagem, de assegurar, por meio de uma declaração, uma posição transparente do mundo.

Apesar de a akrasia ser justamente o que indica, em situações como a do PM, que há como se falar em um acesso das pessoas as suas crenças, a efetividade desse acesso só aparece quando a questão já não é ter evidências para crer ou não em tal e tal, mas quando as declarações que venham a realizar conformem ao modo como normalmente participam de jogos de linguagem 'agindo', quando indicam convicção sobre aquilo que asserem, quando, na asserção, perde-se qualquer referência àquilo que se passa internamente em suas mentes.

Jay David Atlas (2007, p. 133-6) discorda da explicação da tensão presente em sentenças Moore-paradoxais sugerida por Moran. Fundamentalmente, sua crítica concentra-se na impossibilidade de que possamos atribuir alguma razão linguística "para pensar que as pessoas falem ou pensem dicotomicamente desse modo, ou que, ao pensarem sobre si mesmas ao terem crenças sobre o mundo, elas pensem no mundo e em suas respectivas crenças ordinárias transcendendo toda descrição de seus estados psicológicos” (ATLAS, 2007, p. 135). Atlas procura sustentar que a posição de Moran cancela que se possa dizer que foi realizado um proferimento infeliz ou verbalizado um pensamento estranho.

Para Atlas, a tensão não pode ser corretamente alcançada por Moran, visto que não se pode garantir (não há meios para) que as pessoas tenham visões puramente teóricas de si mesmas, assim como supõe Moran no que chama de acesso de terceira pessoa. Atlas sugere que, em casos de pacientes que buscam o tratamento para seus traumas, por exemplo, seus proferimentos não podem ser considerados como visões puramente teóricas, científicas de si mesmos. Afirma, também, que Moran concordaria com essa prerrogativa, já que, como apontamos antes, se houvesse a possibilidade de que as pessoas apenas tivessem o acesso de terceira pessoa sobre suas crenças, então "uma sentença de tipo mooreano descreveria uma possibilidade empírica perfeitamente coerente” (MORAN, 2001, p. 84). A tensão só é mais bem explicada, para Moran, quando a tratamos no âmbito da declaração, quando a questão não invoca mais reportar uma crença, mas declará-la obedecendo a condição da transparência. 
No entanto, a dificuldade de que se faça a crítica do modo como quer Atlas é tentar mostrar que o desacordo presente em sentenças Mooreparadoxais possa ser explicado por razões pragmáticas. Atlas supõe que na primeira metade daquelas conjunções há um uso 'quase performativo' de 'eu creio', cuja função é de "estabelecer a existência de um estado de crença comprometido com a verdade do conteúdo" (ATLAS, 2007, p. 135), e, por ser negado na segunda metade da conjunção, "cria para a totalidade do proferimento um ato de fala indireto que reporta um estado de crença com conteúdo falso" (Id. Ibid), indicando que a dissociação é própria do falante. Por isso, para Atlas, primeiro focamos nossa atenção naquilo que a asserção reporta, e, depois, no fato de o falante também estar comprometido com a totalidade do que asseriu, e não há nada, para o autor (que não considera que haja paradoxo, pois considera haver possibilidades em que sentenças dessa natureza façam sentido), estranho na linguagem usada. Haveria, por parte do falante, competência no uso da linguagem, e nada apontaria para algo que se passa 'dentro' ou 'fora' dele, dada a correção de uso daquilo que proferiu (asseriu).

Entretanto, não acreditamos que Atlas compreenda corretamente aquilo que nos diz Moran. Em primeiro lugar, quando se fala de uma perspectiva teórica, um acesso de terceira pessoa, não quer se indicar um tratamento 'científico', como sugere Atlas, daquilo que se passa internamente às pessoas. Justamente o contrário: não pode ser uma perspectiva científica da questão, já que não temos nenhum regramento que nos permita disciplinar aquilo que constitui uma série de evidências que adquirimos para crer em tal e tal, o que se dá sem uma corrente 'consciência' do que se passa em nossas mentes (assim como não temos consciência do funcionamento de certos órgãos de nosso corpo). Em segundo lugar, aquilo que Atlas considera como científico (a perspectiva de terceira pessoa que temos sobre nós mesmos) é comum nas pessoas quando necessitam enfrentar diversas situações, recorrentes em suas vidas, como no caso de quererem deixar de fumar, mas não encontram suporte (teórico/empírico) para parar de fazê-lo. E, quando tomamos aquilo que as pessoas nos asserem, o fazemos no sentido de tomar ou não aquilo que disseram como evidências para coisas que nós mesmos podemos ou não passar a acreditar. Mas, que evidências podemos tomar de alguém que assere 'está chovendo e não creio' se queremos saber se levamos para a rua, por exemplo, o nosso guarda-chuva?

Quando tomo alguma asserção de outra pessoa para meus próprios propósitos, não o faço apenas porque a pessoa proferiu algo linguisticamente 
adequado, mas o faço na medida em que tenho, a partir do que ela disse, condições de tomar sua fala como evidência para minha ação, pois considero, pela convicção com que disse, que está segura sobre o assunto (muitas asserções linguisticamente adequadas podem não ter significado algum). Nesse sentido é que não há mais remissão direta, na declaração, de quem assere a qualquer perspectiva 'teórica' que tenha de si, muito embora não se possa negar que, de algum modo, a pessoa tenha um tipo de acesso às coisas em que acredita, caso contrário poderíamos considerá-la apenas um autômato. Mas, não é esse o caso.

O caso é que necessitamos de seu posicionamento para tornarmos, de algum modo, efetivas as coisas que ela assere para nós. No entanto, se tornarmos a construir um cenário em que as sentenças Moore-paradoxais são 'percebidas' mediante o recurso de regramentos de atos-de-fala, retornamos ao problema de ter de explicar por quais razões as pessoas asseriram desse modo, e isso nos faria voltar a ter de discutir sua participação na comunicação em vistas de suas intenções, o que dificilmente teremos condições de saber ${ }^{38}$.

Moran denomina de acesso de terceira pessoa um modo a mostrar que há, correntemente em nossas ações, momentos em que parecemos estar diante de possibilidades (necessidades?) de revisão de nossas crenças. Talvez (muito provavelmente) as pessoas não saibam (tecnicamente) o que significa ter esses acessos ou perspectivas teóricas/empíricas sobre si mesmas, mas certamente, no fluxo da vida, elas poderão se lembrar de uma série de circunstâncias nas quais justamente esse é o caso: por exemplo, declaram categoricamente que pararão de fumar, mas permanecem com suas evidências (empíricas/teóricas) de que a tarefa será difícil de ser cumprida. Ao contrário: será justamente quando a dissociação do acesso de terceira pessoa se desmancha que aquilo que asserem vem a ganhar importância nas diversas trocas intercomunicativas (bem como para si próprias, pois realizam o que manifestam categoricamente). Uma vez que as coisas estejam assentadas, então a declaração coloca as pessoas ao nível daquilo que deve ser considerado significativo em suas manifestações transparentes do mundo.

Não fosse esse o caso, seria perfeitamente compreensível uma asserção de sentença Moore-paradoxal; sempre encontraríamos razões para justificar (a nós mesmos, como audiência) aqueles proferimentos absurdos que são nosso

38 Veja-se o segundo capítulo de nossa tese de doutorado (2008) e nosso trabalho de 1999 para conhecer a crítica àquilo que Williams (1994) denominou de 'a estrutura intencional da asserção'. 
objeto de investigação. Pelo contrário, o proferimento de uma sentença Moore-paradoxal revela irracionalidade de parte de um falante. De outro modo, deveríamos manter o desacordo e imaginarmos cenários onde esses proferimentos pudessem fazer sentido. Lembremo-nos de uma passagem das IF, já citada acima, onde Wittgenstein parece sugerir essa questão:

Se escutasse as palavras de minha boca, poderia dizer que outra pessoa falava por meio dela. 'A julgar pelo que disse, isso é em que acredito'. Agora é possível pensar nas circunstâncias em que essas palavras fariam sentido. E então seria possível que alguém dissesse 'Está chovendo e não creio', ou 'Parece que meu ego acredita nisso, mas isso não é verdadeiro'. Alguém teria de apresentar uma figura cujo comportamento indicaria que duas pessoas falavam por minha boca (WITTGENSTEIN, 2001, p. 164).

O problema aqui não é eminentemente linguístico, no sentido de um uso correto da linguagem mediante as regras da gramática de uma língua (como o português), mas cognitivo, principalmente no domínio em que asserções significativas são realizadas, em determinados jogos de linguagem, como passamos a mostrar a seguir analisando as conseqüências de as pessoas estarem em um estado de dissociação ao pensarem ou asserirem sentenças Moore-paradoxais.

Um primeiro ponto a ser discutido é se, ao tentarmos dissolver o PM por meio da discussão da akrasia (a manifestação de um estado de dissociação), não estaríamos deslocando a argumentação do ponto de vista cognitivo para um ponto de vista de volição, buscando o sentido apenas etimológico do conceito, o que não é o caso de uso aqui e poderia ser extremamente problemático à investigação. Pois, do ponto de vista de uma audiência, não se parece ter condições de assegurar porque motivos uma pessoa escolheu (se é que escolheu) realizar tal e tal proferimento sobre uma questão qualquer. Realizar essa leitura, no entanto, nos parece ser reproduzir, de certa forma, o cenário em que soluções ao PM foram forjadas mediante regramentos inter-comunicativos baseados na intencionalidade de falantes ao participarem de atos-de-fala. E, assim como raramente estamos em posição de saber quais são as intenções de falantes em jogos de linguagem (apesar de podermos suspeitar que possam existir intenções por trás da fala), do mesmo modo não estamos em posição de saber por que um falante escolheu asserir uma sentença Moore-paradoxal. 
Pode-se partir da premissa, inclusive, de que a pessoa pode não ter domínio sobre sua asserção de sentença Moore-paradoxal. Em outras palavras, que a pessoa sequer pode saber por que asseriu desse modo. E, invariavelmente há momentos em que isso parece acontecer em casos eminentemente patológicos. No entanto, em que medida a ausência das razões que fizeram com que uma pessoa escolhesse asserir tal e tal sentença Moore-paradoxal pode comprometer uma análise em termos da efetividade de sua declaração? A racionalidade de uma ação dependerá, é o que queremos sustentar, de sua correta participação em jogos de linguagem. Ora, em um estado 'akrático', sejam quais forem as razões que fazem com que esse estado se manifeste, ele cancelará ou prejudicará sua participação em trocas intercomunicativas de muitas naturezas.

Há diferentes graus de irracionalidade nas manifestações públicas que as pessoas realizam. No entanto, minimamente, no caso de uma pessoa que não tenha seu aparato cognitivo alterado por razões patológicas, que tire seu foco do mundo e se diferencie do modo usual como a maior parcela das pessoas adquire suas crenças, então se pode dizer que, em estado 'akrático', uma pessoa sabe que não possui condições de assegurar convictamente que crê em tal e tal ('meu amigo não me persegue, mas creio que ele me persegue' - que convicção posso eu ter a respeito?). Todavia, do mesmo modo que nos proferimentos (aqui, melhor que asserções) de outras pessoas que se encontram patologicamente comprometidas, as suas ações não terão como ser racionalmente sustentadas: "uma crença que não pode ser declarada está cognitivamente isolada, inevitável para processos normais de revisão e revisão que constitui a saúde racional da crença e outras atitudes” (MORAN, 2001, p. 108).

O cuidado de não perdermos o foco da discussão por meio de uma leitura da akrasia como um caso de fraqueza de vontade pode, também, gerar outros mal-entendidos. Aparentemente, poderia não ser irracional que alguém proferisse 'Minha tia faleceu, e não acredito', reiteradas vezes (já que ela gozava de plena saúde e era jovem, por exemplo). Isso se observarmos o jogo de linguagem em que esse proferimento foi realizado. O falante, aqui, não parece estar alegando a convicção de que sua tia não faleceu (com isso, negando, na segunda metade da conjunção, o que disse na primeira metade), mas, simplesmente, essa seria uma maneira de dizer que esse incidente lamentável ocorreu, embora pudesse categoricamente afirmar que sua tia realmente morreu e não se comprometer com o resultado de asserir uma sentença absurda. Agora, se o falante realmente se encontrar em um estado 'akrático' em relação à morte de sua tia, independentemente de isso 
transcender as suas próprias forças, isto é, independentemente de ele poder 'escolher' em que acreditar, sua participação em jogos de linguagem também estará comprometida, em virtude de que sua audiência pode necessitar de seu posicionamento a respeito da questão.

A clareza de por que o PM é um problema eminentemente cognitivo pode ser mais bem notada quando a participação de falantes em determinados jogos de linguagem, ao asserirem sentenças Moore-paradoxais, têm cancelada a possibilidade de que possam sustentar conhecer o assunto em questão. Relembremos: situações 'akráticas' são aquelas que revelam que uma pessoa pode ter acesso sobre suas crenças (em muitos exemplos, caso a pessoa esteja em sua plena saúde mental), mas esse acesso aponta para uma dissociação, já que ela não pode categoricamente afirmar sua convicção sobre o assunto, não pode cumprir a condição da transparência, e, portanto, que terá toda a dificuldade de sustentar 'conhecimento' sobre o assunto em questão.

Por um lado, essa observação é fundamental para que nos distanciemos de uma análise do problema à luz da Concepção Apresentacional. Para os defensores dessa concepção, sempre uma asserção de 'eu creio que $p$ ' equivale a asserção pura e simples de $p$. Mas, nem sempre quando assere 'eu creio que $p$, a pessoa está a falar de $p$, pois pode ser o caso de que não tenha possibilidade de declarar convictamente seu veredicto sobre $p$, como se mostra com exemplos de situações 'akráticas': ela está falando, então (embora em estado de dissociação), de si mesma. Assim, dizer 'eu creio que $p$ ' não é sempre um modo alternativo de dizer $p$, embora em alguns casos esse pareça ser realmente o motivo.

Por outro lado, considere-se que a pessoa, ao não cumprir a condição da transparência por não ter convicção sobre determinado assunto, pode, em certas circunstâncias, estar a negar uma das condições necessárias para ter conhecimento: ter a crença no que diz, comprometendo sua participação (racional) ${ }^{39}$ em certos jogos de linguagem. Darlei Dall'Agnol, em seu artigo Crer e Saber. o Absurdo de Moore analisado a partir de Wittgenstein (2007),

\footnotetext{
39 Várias vezes mencionamos que em situações 'akráticas' um pessoa compromete a racionalidade de sua ação. Agir racionalmente, aqui, deve ser considerado agir de acordo com as regras que orientam determinada prática linguística, no sentido de gramática profunda, e não como uma 'faculdade' de razão, concebida a priori, ou mesmo como um estado em que uma pessoa age de acordo com uma 'disciplina' mental, rigorosamente orientada por princípios epistêmicos, o que consideramos serem ingredientes cuja aplicação prática é deveras problemática (como já vimos destacando desde antes).
} 
observa que o verbo 'saber' tem semelhanças de família, em Wittgenstein, com compreender, entender, cujo uso possível faria com que o austríaco não rejeitasse a definição tradicional de conhecimento para determinado jogo de linguagem: ter conhecimento é ter crença, verdadeira e justificada ${ }^{40}$. Ora, Wittgenstein, em seus últimos escritos, publicados após a sua morte com o título de $D a$ Certeza, exatamente no parágrafo 177 afirma que "aquilo que sei, acredito" (WIIGENSTEIN, s/d, p. 61). Para Dall'Agnol, essa frase mostra que Wittgenstein estava preocupado em estabelecer as regras de um uso do verbo saber, indicando a sua correta aplicação.

No caso das sentenças Moore-paradoxais, o falante não estaria cumprindo as regras para a correta aplicação dos conceitos de 'crer' e 'saber', pois, se "Saber=df acreditar e ter evidências adequadas que justifiquem a crença; crer=df ter a pré-disposição de aceitar a verdade de uma proposição mesmo sem evidências suficientes" (DALL'AGNOL, 2007, p. 22), então o primeiro conjunto seria a manifestação de que 'sei que $p$ ', e, no segundo conjunto, nego poder ter conhecimento sobre $p$, pois nego a crença em $p$ (no caso de 1), ou afirmo a crença no contrário (no caso de 2). Seria correto asserir, por exemplo, 'Creio que está chovendo, embora não o saiba', mas não 'Sei que está chovendo, mas não creio'. Ou seja, tanto no caso de 1, como no caso de 2, não cumpri corretamente o uso dos verbos crer e saber; assim, "o Absurdo de Moore é simplesmente um mau uso de verbos epistêmicos” (DALL'AGNOL, 2007, p. 22).

Mas 'por que' realizei esse mau uso do verbo epistêmico crer? Poderse-ia perguntar por qual razão um falante infringiu as regras corretas do uso desse verbo, e, dessa maneira, estabelecer uma conexão com o que vimos discutindo até aqui. Se for correto realizar a análise em termos do uso, também é correto dizer que, no uso, é pressuposto um modo transparente de indicar como, na perspectiva de primeira pessoa, as coisas estão constituídas para mim. Do ponto de vista de quem pensa ou assere uma sentença Mooreparadoxal, não parece haver "um porto seguro que decidirá qual o acesso é o

\footnotetext{
${ }^{40}$ Sabe-se que a definição de conhecimento, supostamente forjada desde Platão, foi problematizada na década de sessenta com 0 artigo de E. Gettier, É crença verdadeira e justificada conhecimento? É aceito no debate epistemológico que as referidas condições continuam sendo necessárias, porém não suficientes, visto que Gettier sugere contra-exemplos em que há pessoas que têm crença, verdadeira e justificada, mas não têm conhecimento. No entanto, entrar nesse debate foge ao escopo de nossa investigação aqui. Para efeito de nossa análise, basta dizer que, no mínimo, as três condições devem ser cumpridas. Com isso, já se atinge o efeito de mostrar que uma delas é rechaçada quando a pessoa declara sua crença em uma proposição Moore-paradoxal querendo, com ela, sustentar conhecimento.
} 
mais apropriado" (BESUNSAN, 2007, p. 256), se seu acesso de primeira ou seu acesso de terceira pessoa. É justamente por essa razão que a

corrigilibilidade [desses estados] depende dos predicados públicos [grifo nosso] em que são expressas minhas crenças tanto aquelas acessíveis em primeira pessoa quanto aquelas disponíveis para um acesso de terceira pessoa. (...) Vale notar que o conflito de autoridades aqui não nos deixa nenhuma margem para uma estratégia cética tradicional como a epokhé, uma vez que não posso recuar em direção a nenhum tipo de conteúdo comum entre crenças provenientes dos dois tipos de acessos - não há um tal recuo luminoso. Resta apenas a alternativa de estabelecer em cada caso o conteúdo de minha própria crença - tal como fazemos com respeito aos demais temas (anti luminosos) do mundo (Id. Ibid.).

Tanto no caso de 1 , quanto de 2 , aquela pessoa que pensa ou assere as respectivas sentenças encontra-se em estado de dissociação, e uma declaração (conformando a certas regras de uso das palavras) só ganhará efetividade quando esse estado de dissociação é abandonado, colocando em movimento o jogo de linguagem em que uma declaração pode ser realizada. $\mathrm{O}$ absurdo da declaração, quando mantido, torna as sentenças estranhas aos ouvidos de qualquer audiência, afinal, como alguém pode declarar (em uma asserção) que tal e tal, e, logo após, na mesma conjunção, declarar que não crê que esse seja o caso ou que o caso é o contrário? Do ponto de vista da inteligibilidade de seu proferimento, as coisas estão colocadas, aqui, ao nível da irracionalidade.

No caso de 1, a segunda metade da conjunção, o acesso de terceira pessoa, mostra que as suas evidências (empíricas/teóricas) parecem rejeitar o que poderia ser declarado publicamente, e, como uma asserção categoricamente constituída compromete a pessoa com a verdade daquilo que acredita (o que lhe deve ser transparente, como supostamente aconteceria na primeira metade da conjunção), ela nega que tenha esse compromisso logo a seguir. No caso de 2, na segunda metade da conjunção, há indícios (evidências teóricas/empíricas), na perspectiva de terceira pessoa, para a crença no contrário daquilo que seria o compromisso a ser declarado publicamente (o que está na primeira metade da conjunção). Aqui, poderia valer a observação de Baldwin: a pessoa está exposta "a um compromisso que é obviamente [grifo nosso] inconsistente com outro compromisso cuja 
existência o falante também se compromete” (2007, p. 86), não simplesmente a existência de comprometimentos inconsistentes, evitando que se tenha de catalogar inconsistências fortes e fracas para a acusação de irracionalidade.

Como simplesmente ao pensar em uma sentença Moore-paradoxal a pessoa tem os mesmos desafios a enfrentar que em sua manifestação pública $^{41}$, a absurdidade é mantida tanto no âmbito do pensamento, quanto na sua respectiva asserção: a pessoa está impossibilitada de agir racionalmente por meio da declaração, de uma maneira transparente. É justamente por isso que as conjunções absurdas Moore-paradoxais irão cancelar a participação das pessoas em muitos jogos de linguagem, assim como na análise de Dall'Agnol, onde a pessoa nega uma das condições para poder alegar ter conhecimento, pois a capacidade de "declaração é a condição normal e parte do bem-estar racional da pessoa” (MORAN, 2001, p. 108).

No entanto, não é apenas o aspecto absurdo das sentenças Mooreparadoxais que necessita ser dissolvido, mas seu aspecto paradoxal. Não basta explicar o que há de absurdo com a crença ou a asserção de sentenças Mooreparadoxais, mas, também, por que aquilo que pode ser acreditado ou asserido por outra pessoa torna-se absurdo na perspectiva de primeira pessoa.

Consideremos o caso de uma pessoa que tem problemas de relacionamento com seu pai. Após diversas sessões de terapia, seu psicanalista lhe assere: 'a julgar pelo que dizes e me relatas, Teu pai te ama, mas não acreditas'. Como a pessoa deve receber essa asserção? Quando o psicanalista realiza essa declaração, o faz na perspectiva de primeira pessoa, isto é, essa 'constatação' é evidente para ele, revela uma crença que ele, o psicanalista, declara transparentemente sobre a questão: a crença de que seu paciente não crê que é amado pelo pai. Para isso, tomou, da pessoa, uma série de evidências para aquilo que, agora, infere sobre o comportamento dela em relação ao seu pai (como se diz, 'olhando as coisas de fora'). Inicialmente, inclusive, houvera tomado as manifestações de seu paciente sempre entre aspas, pois era patente que o mesmo não sabia dos possíveis sentimentos que realmente tinha em relação a seu pai: o paciente não tinha condições, e, talvez ainda não tenha, de declarar que realmente o seu pai o ama.

\footnotetext{
41 Independentemente de poder escolher ou não estar nesse estado, já que o que se espera de uma pessoa é que possa agir racionalmente em quaisquer situações. Se a pessoa não pode escolher estar ou não nesse estado, seja por patologia ou não, também não o poderá em muitas outras circunstâncias; poderá pensar ou declarar diferentes absurdos e a irracionalidade de suas ações será patente da mesma forma.
} 
O paciente, então, tem agora revelado um possível estado 'akrático': gostaria de declarar categoricamente que seu pai o ama, mas ainda encontra razões (empíricas/teóricas) para desconfiar que possa fazê-lo. No entanto, é possível que agora realize um "ajuste racional de suas crenças" (MORAN, 2001, p. 112), e passe a agir de acordo com a nova descoberta: 'É verdade, meu pai me ama', quando terá nova crença assentada, a qual poderá, a partir disso, ser categoricamente declarada (avowed). Esta é, agora, sua crença sobre o assunto. Não fosse isso possível, não haveria terapia que pudesse solucionar traumas psicológicos das pessoas. Quando uma nova crença é assentada e pode ser categoricamente declarada, como no caso desse hipotético paciente, torna-se razão para suas ações presentes e futuras, constitui-se como uma forma de autoridade sobre aquilo que está a sua disposição: "qualquer estado representacional terá um duplo aspecto, um sobre o qual se trata da transparência do mundo de certo modo, outro sobre o qual realiza uma contribuição para a conduta do agente” (MORAN, 2001, p. 130). Se o paciente não tiver razões suficientes (que podem advir das observações de seu psicanalista ou de outras formas) para assegurar a nova crença de que seu pai o ama, então continuará a fazer o que sempre fazia (por exemplo, maltratar seu pai, etc.). A ideia é a de que, na declaração, a pessoa assume responsabilidades sobre aquilo que faz, no sentido de que tem convicção (por ter a crença assentada) sobre aquilo que costuma declarar.

Assim, o que parece permitir que haja o que chamamos de transmissibilidade de crenças é a possibilidade de que as pessoas passem a declarar suas crenças, para as quais não mais haverá, nesse momento, nenhuma remissão a outras evidências (teóricas/empíricas) que antes poderiam causar certo estado de dissociação. Em casos felizes, pois, o paciente não receberá a sentença Moore-paradoxal ipsis literis, 'meu pai me ama e não acredito', mas, simplesmente, 'eu não acredito que meu pai me ama', visto que, no primeiro caso, nada estaria resolvido para si em nenhum sentido, apenas seria a revelação de seu estado 'akrático ${ }^{\text {,2 }}$. O tratamento da questão terminaria, então, quando o paciente pode declarar (exprimindo

\footnotetext{
42 Novamente, poderia surgir a objeção de que o paciente talvez não tivesse, dado um conjunto de razões patologicamente diagnosticadas, condições de 'fugir' de seu estado 'akrático'. Ora, em que medida isso afetaria que considerássemos também irracional o modo como participa de diferentes e importantes jogos de linguagem, por exemplo, em que parece alegar ter conhecimento sobre o que assere, sobre suas próprias crenças?
} 
convicção) que realmente seu pai o ama, e não há mais dúvidas, de sua parte, sobre a questão:

A transição da atribuição para a declaração é então uma expressão da liberdade racional das pessoas, uma asserção de autoridade. É esta asserção, este comprometimento, que torna possível que sua declaração esteja em conformidade com a Condição da Transparência, o anúncio de sua crença sem a confiança nas evidências psicológicas sobre si. Nesse ponto, a proposição ganha aceitação mais adiante como base para seu pensamento, prático e teórico. E isso expressa controle em sua auto-reflexão para justificar razões sobre aquelas explicativas, pois as premissas para raciocinar não são proposições sobre suas crenças, mas proposições sobre os objetos de suas crenças, os próprios fatos. Isso expressa a relação de alguém com seu próprio estado mental que é exclusivamente de primeira pessoa e não repartido pelas melhores telepatias de nossa imaginação filosófica. $\mathrm{O}$ agente está no centro da figura porque se posso declarar minha crença, e então falar de minha mente sem o suporte de evidência sobre mim mesmo, em qualquer contexto, estou falando do que creio estar a meu dispor (MORAN, 2001, p. 151).

Se eu for o paciente, em ambas as declarações, a minha e a do psicanalista, é requerido que o que seja declarado o seja de forma transparente. Mas, se quero ser transparente em relação à determinada declaração, antes disso preciso me livrar do estado 'akrático', desse estado de dissociação que compromete minha racionalidade. Então, o problema não será simplesmente sustentar 'a mesma proposição' que meu terapeuta, mas garantir que o resultado da terapia me foi eficiente, e só será eficiente se não vier a sustentar publicamente uma sentença Moore-paradoxal.

\subsection{Respondendo a condição C}

A Condição $C$ nos pede para mostrar em que sentido aquela pessoa que crê ou assere uma sentença Moore-paradoxal 'parece' estar se contradizendo. A resposta já parece sugerida a partir do que vimos discutindo antes. Como, ao realizar uma declaração, me comprometo 
categoricamente com aquilo que asseri, pois, desse modo, obedeço a Condição da Transparência, então, no caso de 1, comprometo-me, na primeira metade da conjunção, com determinado estado de coisas. Mas, na segunda metade da conjunção, nego ter esse comprometimento, cancelando que minha audiência possa tomar o que asseri como evidência para possíveis crenças que eu possa formar sobre o assunto, mostrando que estou em estado dissociado ('akrático') a respeito da questão. Esse estado de dissociação, mesmo quando apenas pensado, retira das pessoas as condições para que possam realizar quaisquer ações racionais com respeito a um assunto qualquer (então, o problema não reside só na fala, embora sua manifestação que realmente obstruirá determinadas trocas intercomunicativas).

Aqui, é plausível notarmos que não há uma equivalência direta entre uma sentença Moore-paradoxal e uma contradição formal, há uma semelhança entre ambas. Quando alguém crê ou assere uma contradição, do mesmo modo que quando assere uma sentença Moore-paradoxal da forma 1 compromete a sua correspondente ação racional, paralisando determinada prática linguística por não respeitar as regras que comumente são aceitas para tal fim.

No caso de 2, embora a crença ou a declaração da respectiva sentença Moore-paradoxal indique uma inconsistência nas crenças da pessoa, e não a negação da respectiva crença pensada ou asserida, isto é, que tem mais evidências para crer no contrário daquilo que poderia declarar categoricamente, o problema reside em uma dissociação que é óbvia no mesmo 'pensamento' ou asserção. Assim, esse estado de dissociação também é semelhante a uma crença ou asserção de contradição formal, pois também compromete possíveis ações (racionais) da pessoa (e conseqüentes declarações) em vistas de determinados propósitos. É concedido que as pessoas sejam, em muitas circunstâncias, inconsistentes, mas o que parece estranho é quando essa inconsistência aparece patente na mesma conjunção, pensada ou $\operatorname{asserida}^{43}$.

\footnotetext{
${ }^{43}$ Se utilizarmos determinados princípios epistêmicos para mostrar que ter a crença em não-p implica não ter a crença em $p$, ter-se-ia equivalência entre 1 e 2, e talvez as coisas ganhassem uma forma que satisfaria melhor a percepção do sentido em que 2 parece ser 'contraditória'. Entretanto, queremos evitar 0 uso de princípios epistêmicos para dar conta do PM; queremos, simplesmente, mostrar como 0 problema se dissolve se observamos corretamente como determinadas regras influenciam aquilo que pode ser pensado e consequentemente asserido corretamente em certos jogos de linguagem, por meio de declarações. Quando alguém pode declarar tal e tal, e isso é realizado categoricamente, com convicção, sem mais o apoio de nenhuma evidência, então parece que, tanto no caso de 1 , quanto de 2 ,
} 
Ter um aspecto de contradição, faz com que 1 e 2 mostre "que a lógica não é tão simples como pensam os lógicos” (WITTGENSTEIN, 1974, p. 177). No entanto, se poderia insistir que se deve mostrar que as negações de 1 e 2 deveriam, por ter semelhança com contradições, serem tautologias, o que não parece se dar "mesmo nas bocas dos nossos mais sensacionais meteorologistas” (SORENSEN, 1988, p. 15). Por exemplo, a negação de 2 poderia ser 'ou não está chovendo ou eu creio que está chovendo' (DE ALMEIDA, 2001, p. 40) e a de 1 seria logicamente equivalente a 'creio que está chovendo somente se não está' (Id. Ibid), nenhuma das duas, pois, tautologias. Mas, as coisas não estão corretamente compreendidas quando se faz essa reivindicação.

Pergunta-se se a contradição é compreendida como um mau uso da linguagem ou um fragmento de discurso não literal (DE ALMEIDA, 2001, p. 41). E, a pergunta não é sem cabimento, pois muitas vezes esse ponto aparece confuso, devido à gama de diferentes jogos de linguagem. Evitar a contradição é visto como condição sine qua non à racionalidade epistêmica, e, por isso, há dificuldade em se compreender o uso não-literal de contradições em determinados contextos.

Por exemplo, pode-se usar a expressão 'Chove e não chove' como fragmento de discurso não-literal para indicar que nem chove torrencialmente, nem que o tempo está bom, mas que está garoando - você consideraria essa pessoa, nesse jogo de linguagem, irracional? O contexto em que uma proposição contraditória é asserida é fundamental para se tentar entender o ponto. A participação (racional) de um falante depende dessa observação. Se alguém me pergunta se a Lua é um satélite, não posso dizer 'A Lua é e não é um satélite', se tenho que garantir conhecimento sobre o assunto. Evidentemente que me comprometeria uma contradição nesse caso. A noção de falsidade lógica, do modo como a lógica clássica a compreende, é factível no caso.

Do 'mau uso da linguagem', entretanto, também se pode inferir casos em que as pessoas 'parecem estar se contradizendo', mesmo embora o parentesco, aqui, não signifique reduzir simplesmente um caso a outro, reduzir uma declaração de sentença Moore-paradoxal a um caso de contradição. Fosse isso, a Concepção Apresentacional já teria dado conta do

há certo aspecto 'contraditório' envolvido, prejudicando, em ambos os casos, as ações racionais das pessoas que pensam ou asserem essas sentenças, assim como ao pensarem e/ou asserirem uma contradição em determinadas circunstâncias. 
problema ao sugerir a equivalência entre a expressão 'eu creio que $p$ ' e ' $p$ ', o que nem sempre é o caso, se observadas as nossas citadas situações 'akráticas'.

Há jogos de linguagem onde o resultado da declaração revela irracionalidade, tanto a declaração de uma contradição formal, quanto de uma sentença Moore-paradoxal. No caso de 'pensamentos' ou asserções públicas (declarações) de sentenças Moore-paradoxais uma regra lógica continua sendo uma regra lógica, mas em um sentido gramatical profundo, em um cenário que deve superar a compreensão clássica de 'contradição', pois diz respeito ao modo como comumente as pessoas costumam declarar o que acreditam (categoricamente), e cujo compromisso elas rejeitam (1) ou alegam ter compromisso com o contrário do que está na primeira metade da conjunção (2). Por isso, a questão é mais 'olhar' para como funcionam nossos jogos de linguagem, e menos sistematizar esses jogos por meios demasiado técnicos que, no fluxo da vida, se mostram inúmeras vezes implausíveis e forçosamente abstratos. 


\section{Referências Bibliográficas}

ATLAS, J. D. What Reflexive Pronouns tells us about belief: a new Moore's paradox

De Se, Rationality, and Privileged Access. (In: GREEN, M \& WILLIAMS, J. (comp.) Moore's Paradox: New Essays on Belief, Rationality, and the First Person). New York: Oxford University Press, 2007, p. 117-145.

BAKER, G. P. \& HACKER, P. M. S. Scepticism, Rules and Language. Oxford: Basil Blackwell, 1984.

BALDWIN, T. G. E. Moore. London and New York: Routledge, 1990.

. The Normative Character of Belief. (In: GREEN, M \& WILLIAMS, J. (comp.) Moore's Paradox: New Essays on Belief, Rationality, and the First Person). New York: Oxford University Press, 2007, 76-89.

BESUNSAN, H. O pensamento sem luz própria (paradoxo de Moore e anti luminosidade). (In: SMITH, P. J. e SILVA FILHO, W., Ensaios sobre o ceticismo). São Paulo: Alameda Casa Editorial, 2007.

BESUNSAN, H. \& PINEDO, M. When my own beliefs are nor first-personal enough. Theoria, n. 58, p. 35-41, 2007.

COLLINS, A. W. Moore's Paradox and Epistemic Risk. The Philosophical Quaterly, n. 46, pp. 308-319, 1996.

CRIMMINS, M. I falsely believe that p. Analysis, n. 52, 1992, p. 191.

DALL'AGNOL, D. Crer e Saber: O Absurdo de Moore analisado a partir de Wittgenstein. Dissertatio, 2007, p. 9-26. Disponível em: http://www.ufpel.edu.br/isp/dissertatio, acesso em 02/10/2008.

DE ALMEIDA, C. Moore's Paradox. (In: AUDI, R. (Ed.) The Cambridge Dictionary of Philosophy). Cambridge: Cambridge University Press, 2a. Ed., 1999.

. What Moore's Paradox is About. Philosophy and phenomenological research, Volume LXII, Number I, January, 2001, p. 33-58.

Moorean Absurdity: An Epistemological Analysis. (In: GREEN, M \& WILLIAMS, J. (comp.) Moore's Paradox. New Essays on Belief, Rationality, and the First Person). New York: Oxford University Press, 2007, p. 53-75.

FARIA, P. E. Le Guêpier de Moore. In: Laugier, S. (org). Wittgenstein: méthaphysique et jeux de langage. Paris: Presses Universitaires de France, 2001, p. 129-152.

GIANOTTI, J. A. Apresentação do Mundo: considerações sobre o pensamento de L. Wittgenstein. São Paulo: Companhia das Letras, 1995. 
GILliES, A. A New solution to Moore's Paradox. Philosophical Studies, n. 105, 2001, p. 237-50.

GLOCK, H. J. Wittgenstein: a critical reader. Oxford: Blackwell, 1996.

. Dicionário Wittgenstein. Tradução de Helena Martins. Revisão de Luiz

Carlos Pereira. Rio de Janeiro, Jorge Zahar Editor, 1998.

GOLDSTEIN, L. Moore's paradox. (In: ENGEL, P. (ed.) Believing and Accepting).

Dordrecht: Kluwer Academic Publishers, 2000, p. 65-92.

GOMBAY, A. Some Paradoxes of Counterprivacy. Philosophy, n. 63, pp. 191-210, 1988.

GREEN, M \& WILliaMS, J. (comp.) Moore's Paradox. New Essays on Belief, Rationality, and the First Person). New York: Oxford University Press, 2007.

GRICE, P. Logic and Conversation. (In: GRICE, P. Studies in the Way of Words). Cambridge, MA: Harvard University Press, 1987, pp. 22-40.

HACKER, P. M. S. Wittgenstein's Place in Twentieth-Century Analytic Philosophy. Oxford: Blackwell, 1996.

- Sobre a autoridade de primeira pessoa. Tradução de Plínio Smith. In:

SMITH, P. (Org). Davidson e a filosofia. São Paulo: Loyola, 2005.

HEAL, J. Moore's Paradox: A Wittgensteinian Approach. Mind, n. 103, pp. 5-24, 1994.

HEBECHE, L. O mundo da consciência: ensaio a partir da filosofia da psicologia de L. Wittgenstein. Porto Alegre: Edipuc, 2002.

HINTIKKA, J. Knowledge and Belief: an introduction to the logic of the two notions. 2a. ed. New York, Ithaca: Cornell University, 1969.

. Uma investigação sobre Wittgenstein. Tradução de Enid Abreu Dobranszky. Campinas: Papirus, 1994.

HUEMER, M. Moore's Paradox and the Norm of Belief. (In: NUCCETELLI, S. \& SEAY, G. Themes from G. E. Moore: new essays in epistemology and ethics). Oxford: Oxford University Press, 2007.

JONES, O. R. Moore’s Paradox, Assertion and Knowledge. Analysis, n. 51, v. 4, pp. 183-186,1991.

KIND, A. Shoemaker, self-blindness and Moore's paradox. The Philosophical Quaterly. V. 53, n. 210, p. 39-48, 2003.

KRIEGEL, U. Moore's Paradox and the structure of conscious belief. Erkenntnis, n. 61, p. 99-121, 2004. 
LINVILLE, K. and RING, M. Moore's Paradox Revisited. Synthese, n. 87, pp. 295-309, 1991.

LINVILLE, K. Wittgenstein on 'Moore's Paradox'. (In: LUCKHARDT, C. G. Wittgenstein: sources and perspectives). Bristol: Thoemmes Press, 1996.

MC GINN, M. Wittgenstein and the Philosophical Investigations. Oxford: Routledge, 1997.

MALCOLM, N. Disentangling Moore's Paradox (In his: “Wittgensteinian Themes: Essays”, 1978-1989, ed. by G. H. von Wright). Ithaca and London: Cornell University Press, 1995.

MARTINICH, A. P. Conversational Maxims And Some Philosophical Problems. Philosophical Quaterly. Ano 30, n. 120, pp. 215-228, 1980.

MOORE, G. E. Reply to my Critics. In: SCHILPP, P. (Editor). The Philosophy of G. E. Moore, La Salle, Ill.: Open Curt, 1942. . Russell's 'Theory of Descriptions'. In: SCHILPP, P. (Editor). The Philosophy of Bertrand Russell. La Salle, Ill.: Open Curt, 1944.

. Moore's Paradox (In: G. E. Moore: Select Writings), ed. por Baldwin, T. London and New York: Routledge, 1993, p.207-212.

MORAN, R. Authority and Estrangement. an essay on self-knowledge. Princeton: Princeton University Press, 2001.

. Self-knowledge, Discovery, Resolution, and Undoing. European Journal of Philosophy, n. 5, p. 141-61, 1997.

MORTARI, C. A. Lógicas Epistêmicas. In: Luiz Henrique de A. Dutra. (Org.). Nos Limites da Epistemologia Analítica. Florianópolis: NEL/UFSC, 1999, v. , p. 17-68.

MOSER, P. K., MULDER, D. H., TROUT, J. D., A teoria do conhecimento: uma introdução temática. Tradução de Marcelo Brandão Cipolla. São Paulo: Martins Fontes, 2004.

NEVES FILHO, E. F. das. O Paradoxo de Moore é apenas um caso de asserção absurda? Revista Grifos, n. 8, p.73-96, 1999.

. O Paradoxo de Moore: a aproximação wittgensteiniana. Revista Grifos, n. 12, p. 69-77, 2002.

. Sobre o saber que e o saber como. (In: DALBOSCO, C., CASAGRANDA, E., MÜHL, E. H., Filosofia e Pedagogia: aspectos históricos e temáticos). Campinas: Autores Associados, 2008. 
. O paradoxo de Moore e a declaração: consequências do choque de acessos de primeira e terceira pessoas. 2008. Tese (Doutorado em Filosofia). Florianópolis: UFSC, 2008.

SHOEMAKER, S. Moore's Paradox and Self-Knowledge. In: SHOEMAKER, S. The First-Person Perspective and Other Essays. Cambridge: Cambridge University Press, 1996, pp.74-93.

SORENSEN, R. A. Blindspots. Oxford and New York: Oxford University Press, 1988, pp.1-456.

. R. Moore's problem with iterated belief. Philosophical Quaterly, v. 36, p. 504-13, 2000.

. Moore's Paradox. (In: DANCY, J. \& SOSA, E. (Editores). A Companion to Epistemology). Oxford: Basil Blackwell, pp. 285-286,1992.

STROLL, A. Moore and Wittgenstein on Certainty. Oxford: Oxford University Press, 1994.

STROUD, B. Mind, meaning, and practice. (In: SLUGA, H, \& STERN, D. G., The Cambridge Companion to Wittgenstein). Cambridge: Cambridge University Press, 1996.

WELBOURnE, M. More on Moore. Analysis, n. 52, v. 4, p. 237-241, 1992.

WILlIAMS, J. N. Moore's Paradox: One or Two. Analysis, n. 39, v. 3, pp.141-142, 1979.

. The Absurdities of Moore's Paradoxes. Theoria, n. 48, v. 1, pp. 38-46, 1982.

. Believing the Self-Contradictory. American Philosophical Quaterly, n. 19, v. 3, pp. 279-285, 1982.

Moorean Absurdity and the Intentional 'Structure' of Assertion. Analysis, 54, pp. 160-166, 1994.

. Moorean Absurdities and the Nature of Assertion. Australasian Journal of Philosophy, 74, n.1, pp. 135-149, 1996.

. Wittgensteinian accounts of Moorean Absurdity. Philosophical Studies, n. 92, p. 283-306, 1998.

. Moore's Paradox and Evans's Principle. (In: GREEN, M \& WILLIAMS, J. (comp.) Moore's Paradox. New Essays on Belief, Rationality, and the First Person). New York: Oxford University Press, 2007.

WILDE, C. Certainty. a discussion of Wittgenstein's notes On Certainty. Manchester: The Open University Press, 1977.

WITTGENSTEIN, L. Philosophical Investigations. 3a. Ed. Oxford: Blackwell, 2001. 
. Remarks on the Philosophy of Psycology. v. I.. Oxford: Basil Blackwell, 1980.

. Da Certeza. Tradução de Maria Elisa Costa. Edição Bilíngüe. Revisão de Tradução de Antônio Fidalgo. Lisboa, Edições 70.

Letters to Russell, Keynes and Moore. Edit. By G. H. von Whright. Oxford: Blackwell, 1974.

. Ultimos escritos sobre Filosofia de la Psicologia. Estúdios preliminares para

la parte II de las Investigaciones Filosóficas. Edición preparada por G. H. VON WRIGHT y HEIKKI NYMAN. Traducción de Edmundo Fernandez, Encarna Hidalgo y Pedro Mantas. Madrid: Tecnos S. A., 1987.

VAHID, H. Moore's Paradox and Evan's Principle: a reply to Williams. Analysis, n. 65 , p. 337-41, 2005.

E-mail: eduardofnfilho@yahoo.com.br

Recebido: novembro/2009

Aprovado: dezembro/2009 